\title{
ZUSGS
}

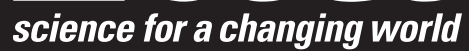

Prepared in cooperation with Consolidated Utilities LLC

\section{Simulated Effects of Lower Floridan Aquifer Pumping on the Upper Floridan Aquifer at Barbour Pointe, Chatham County, Georgia}

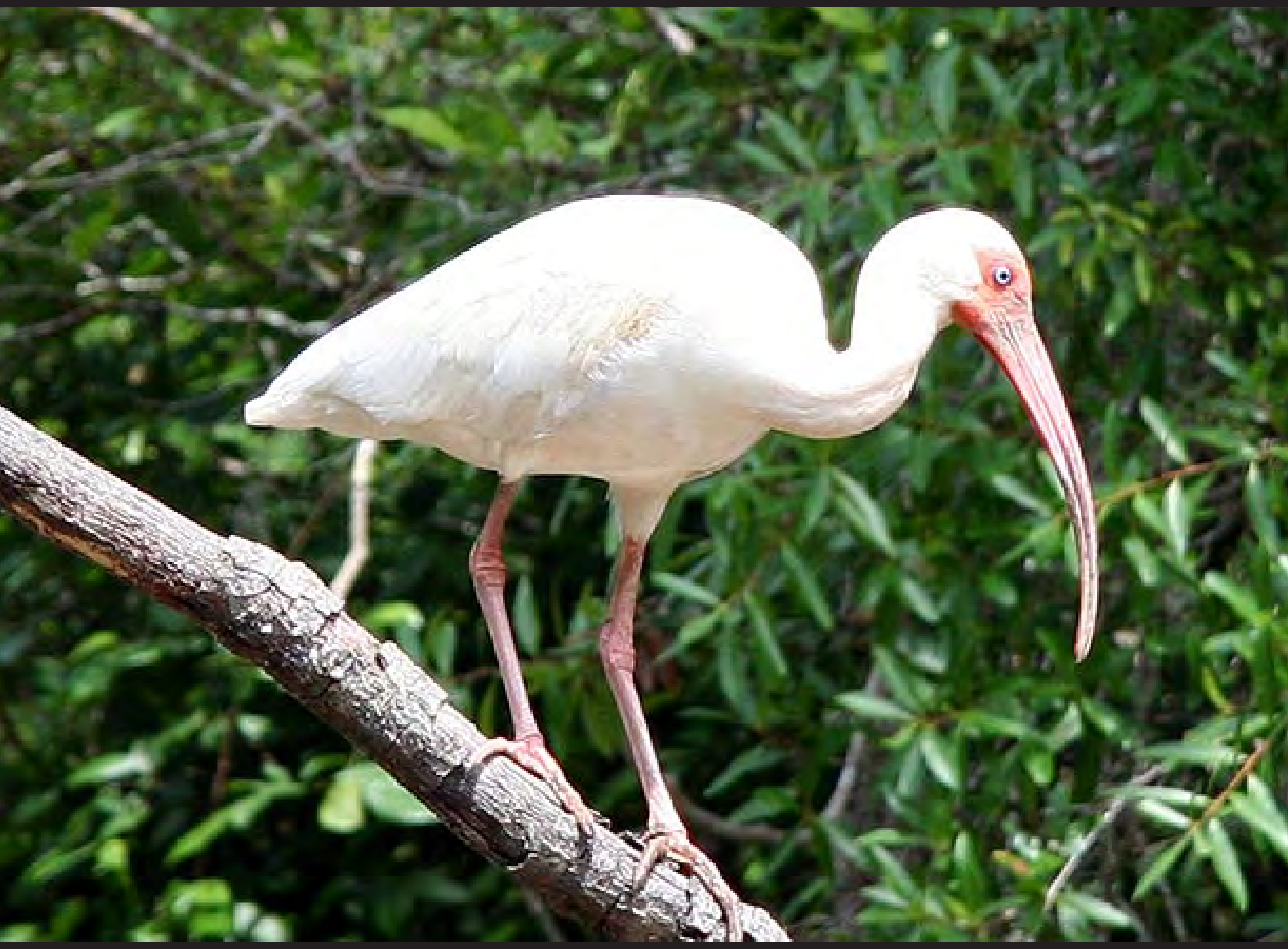

Scientific Investigations Report 2017-5085

U.S. Department of the Interior

U.S. Geological Survey 
Cover. American white ibis (Eudocimus albus) near Altamaha River in McIntosh County, Georgia. Photograph by Alan Cressler, U.S. Geological Survey, 2006. 


\section{Simulated Effects of Lower Floridan Aquifer Pumping on the Upper Floridan Aquifer at Barbour Pointe, Chatham County, Georgia}

By Gregory S. Cherry and John S. Clarke

Prepared in cooperation with Consolidated Utilities LLC

Scientific Investigations Report 2017-5085 


\title{
U.S. Department of the Interior \\ RYAN K. ZINKE, Secretary
}

\section{U.S. Geological Survey William H. Werkheiser, Acting Director}

\author{
U.S. Geological Survey, Reston, Virginia: 2017
}

For more information on the USGS - the Federal source for science about the Earth, its natural and living resources, natural hazards, and the environment-visit https://www.usgs.gov or call 1-888-ASK-USGS.

For an overview of USGS information products, including maps, imagery, and publications, visit https://store.usgs.gov.

Any use of trade, firm, or product names is for descriptive purposes only and does not imply endorsement by the U.S. Government.

\footnotetext{
Suggested citation:

Cherry, G.S., and Clarke, J.S., 2017, Simulated effects of Lower Floridan aquifer pumping on the Upper Floridan aquifer at Barbour Pointe, Chatham County, Georgia: U.S. Geological Survey Scientific Investigations Report 2017-5085, 34 p., https://doi.org/10.3133/sir20175085.
}

ISSN 2328-0328 (online) 


\section{Contents}

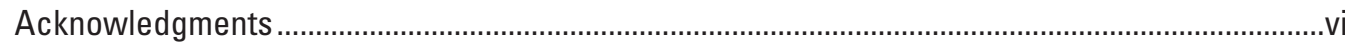

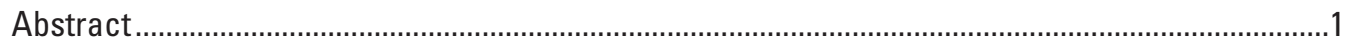

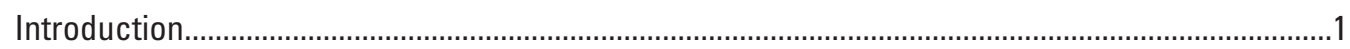

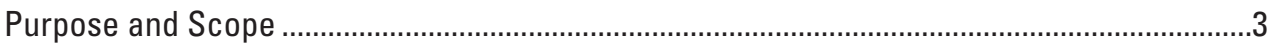

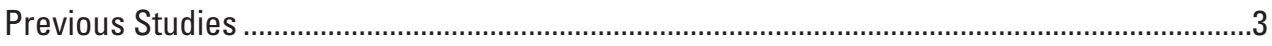

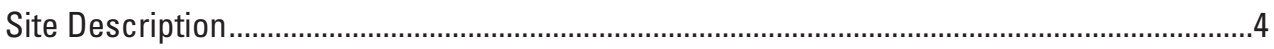

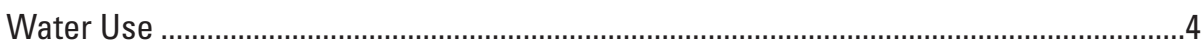

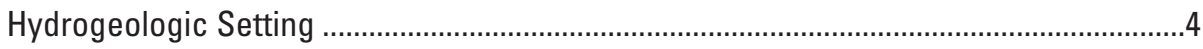

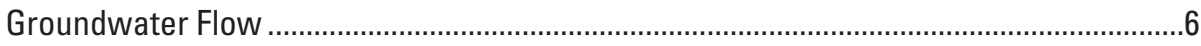

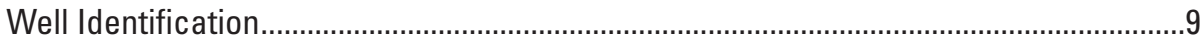

Simulated Effect of Lower Floridan Aquifer Pumping on the Upper Floridan Aquifer.......................9

Observed Water-Level Response..................................................................................................

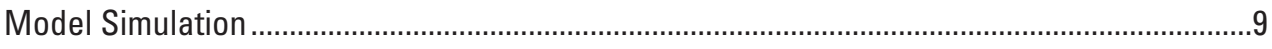

Interaquifer Leakage and Drawdown Response.........................................................12

Upper Floridan Aquifer Drawdown Offset ................................................................17

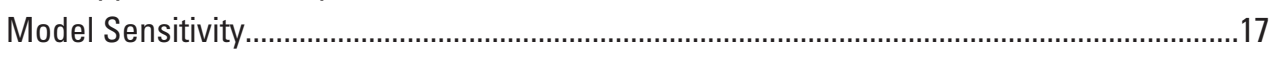

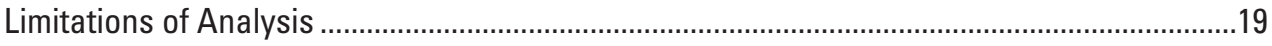

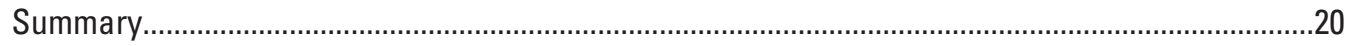

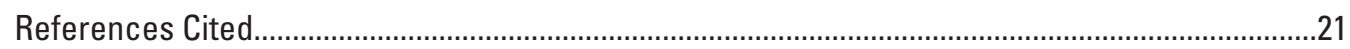

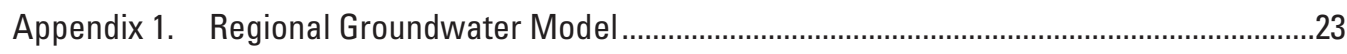

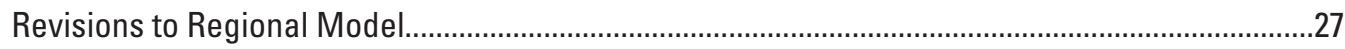

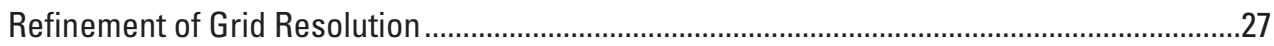

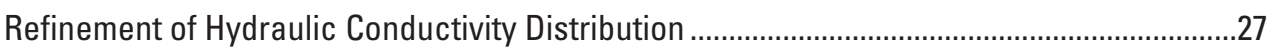

Simulation of Observed Drawdown in Pumped Well.............................................................30

Comparison of Revised to Original Regional Model ......................................................................30

\section{Figures}

1. Map showing location of Barbour Pointe test site Chatham County, Georgia, and potentiometric surface of the Upper Floridan aquifer in coastal Georgia, 1998.

2. Generalized correlation chart showing geologic and hydrogeologic units and model layers in the Coastal Plain of Georgia .

3. Geophysical properties, electromagnetic flowmeter survey, and specific conductance of discharging formation water, test hole for Lower Floridan aquifer well 360398, Barbour Pointe, Chatham County, Georgia

4. Schematic diagram showing conceptual model of predevelopment and modern-day flow system.

5. Graphs showing fit of synthetic water levels to measured water levels for Lower Floridan aquifer pumped well 360398, Barbour Pointe, Georgia, November 16-December 1, 2013. 
6. Fit of synthetic water levels to measured water levels for Upper Floridan aquifer well 360399, Barbour Pointe, Georgia, November 16-December 1, $2013 .$.

7-9. Maps showing-

7. Simulated steady-state drawdown in the Lower Floridan aquifer for scenario A-pumping Lower Floridan aquifer well 360398 at 750 gallons per minute, Barbour Pointe, Georgia, and vicinity

8. Simulated steady-state drawdown in the Upper Floridan aquifer for scenario A-pumping Lower Floridan aquifer well 360398 at 750 gallons per minute, Barbour Pointe, Georgia, and vicinity

9. Simulated Upper Floridan aquifer potentiometric surface for the year 2000 base case and scenario A, Barbour Pointe, Georgia, and vicinity

1-1. Map and diagram showing location of selected wells, regional groundwater model and boundary conditions, and revised model grid, city of Berwick, Fort Stewart, Barbour Pointe, Georgia, and vicinity

1-2. Schematic diagram showing model layers and boundary conditions

1-3. Map showing simulated hydraulic-property zones by model layer. Table 1-1 lists hydraulic conductivity values assigned to zones.

1-4. Map showing difference between simulated and observed water levels by model layer for 2000, revised regional flow model. Brunswick aquifer system, Upper Floridan aquifer, and Lower Floridan aquifer

1-5. Graphs showing observed and simulated water levels in model layers 3, 5, and 7, revised groundwater model.

\section{Tables}

1. Summary of data collected at sites in the Lower Floridan aquifer in coastal Georgia

2. Description of model scenarios and simulated drawdown in the Upper and Lower Floridan aquifers for various pumping distributions at

Barbour Pointe, Georgia.

3. Simulated steady-state water budgets for 2000 and for scenario A, after pumping 750 gallons per minute at Lower Floridan aquifer well 360398,

Barbour Pointe, Chatham County, Georgia.

4. Simulated steady-state water budgets for base case (year 2000) and for scenario $B$, after pumping 240 gallons per minute at Upper Floridan aquifer well 360399,

Barbour Pointe, Chatham County, Georgia.

1-1. Horizontal and vertical hydraulic conductivity values assigned to hydraulic-property zones

1-2. Water-level calibration statistics for the original and revised regional models, base case simulation

1-3. Comparison of simulated water budget by model layer between the original and revised regional models, base case and revised regional models, base case simulation 


\section{Conversion Factors}

Inch/Pound to SI

\begin{tabular}{|c|c|c|}
\hline Multiply & By & To obtain \\
\hline \multicolumn{3}{|c|}{ Length } \\
\hline inch (in.) & 2.54 & centimeter $(\mathrm{cm})$ \\
\hline foot $(\mathrm{ft})$ & 0.3048 & meter $(\mathrm{m})$ \\
\hline mile (mi) & 1.609 & kilometer $(\mathrm{km})$ \\
\hline \multicolumn{3}{|c|}{ Area } \\
\hline square foot $\left(\mathrm{ft}^{2}\right)$ & 929.0 & square centimeter $\left(\mathrm{cm}^{2}\right)$ \\
\hline square foot $\left(\mathrm{ft}^{2}\right)$ & 0.0929 & square meter $\left(\mathrm{m}^{2}\right)$ \\
\hline square mile $\left(\mathrm{mi}^{2}\right)$ & 259.0 & hectare (ha) \\
\hline square mile $\left(\mathrm{mi}^{2}\right)$ & 2.590 & square kilometer $\left(\mathrm{km}^{2}\right)$ \\
\hline \multicolumn{3}{|c|}{ Volume } \\
\hline gallon (gal) & 0.003785 & cubic meter $\left(\mathrm{m}^{3}\right)$ \\
\hline \multicolumn{3}{|c|}{ Flow rate } \\
\hline foot per day $(\mathrm{ft} / \mathrm{d})$ & 0.3048 & meter per day $(\mathrm{m} / \mathrm{d})$ \\
\hline gallon per minute (gal/min) & 0.06309 & liter per second $(\mathrm{L} / \mathrm{s})$ \\
\hline million gallons per day (Mgal/d) & 0.04381 & cubic meter per second $\left(\mathrm{m}^{3} / \mathrm{s}\right)$ \\
\hline \multicolumn{3}{|c|}{ Precipitation } \\
\hline inch per month $(\mathrm{in} / \mathrm{mo})$ & 25.4 & millimeter per month $(\mathrm{mm} / \mathrm{mo})$ \\
\hline inch per year (in/yr) & 25.4 & millimeter per year $(\mathrm{mm} / \mathrm{yr})$ \\
\hline \multicolumn{3}{|c|}{ Specific capacity } \\
\hline gallon per minute per foot & 0.207 & liter per second per meter $[(\mathrm{L} / \mathrm{s}) / \mathrm{m}]$ \\
\hline$[(\mathrm{gal} / \mathrm{min}) / \mathrm{ft})]$ & & \\
\hline \multicolumn{3}{|c|}{ Hydraulic conductivity } \\
\hline foot per day (ft/d) & 0.3048 & meter per day $(\mathrm{m} / \mathrm{d})$ \\
\hline \multicolumn{3}{|c|}{ Transmissivity* $^{*}$} \\
\hline foot squared per day $\left(\mathrm{ft}^{2} / \mathrm{d}\right)$ & 0.0929 & meter squared per day $\left(\mathrm{m}^{2} / \mathrm{d}\right)$ \\
\hline
\end{tabular}

Temperature in degrees Fahrenheit $\left({ }^{\circ} \mathrm{F}\right)$ may be converted to degrees Celsius $\left({ }^{\circ} \mathrm{C}\right)$ as follows:

${ }^{\circ} \mathrm{C}=\left({ }^{\circ} \mathrm{F}-32\right) / 1.8$ 


\section{Datum}

Vertical coordinate information is referenced to the North American Vertical Datum of 1988 (NAVD 88).

Horizontal coordinate information is referenced to North American Datum of 1983 (NAD 83).

Altitude, as used in this report, refers to distance above the vertical datum.

\section{Supplemental Information}

*Transmissivity: The standard unit for transmissivity is cubic foot per day per square foot times foot of aquifer thickness [(ft $\left.\left.\mathrm{ft}^{3} \mathrm{~d}\right) / \mathrm{ft}^{2}\right] \mathrm{ft}$. In this report, the mathematically reduced form, foot squared per day $\left(\mathrm{ft}^{2} / \mathrm{d}\right)$, is used for convenience.

Specific conductance is given in microsiemens per centimeter at 25 degrees Celsius $\left(\mu \mathrm{S} / \mathrm{cm}\right.$ at $\left.25^{\circ} \mathrm{C}\right)$.

\section{Abbreviations}

FAS

Floridan aquifer system

GaEPD

Georgia Environmental Protection Division

$\mathrm{K}_{\mathrm{h}}$ horizontal hydraulic conductivity

$\mathrm{K}_{v}$ vertical hydraulic conductivity

LFA Lower Floridan aquifer

LFCU Lower Floridan semiconfining unit

RMSE root-mean-square error

UFA Upper Floridan aquifer

USGS U.S. Geological Survey

\section{Acknowledgments}

The authors thank Tony Abbott of Consolidated Utilities LLC for his support during this investigation. Ron Kolat of $\mathrm{H}+\mathrm{K}$ Engineering Group helped develop the plan of study and coordinated project drilling with testing activities performed by the U.S. Geological Survey (USGS) at the test site. Dr. James Kennedy, State Geologist, Georgia Environmental Protection Division (GaEPD), provided valuable feedback and comments during the review process.

Debbie W. Gordon, and Conner J. Haugh, USGS, provided valuable technical reviews and suggestions to improve this report. 


\title{
Simulated Effects of Lower Floridan Aquifer Pumping on the Upper Floridan Aquifer at Barbour Pointe, Chatham County, Georgia
}

\author{
By Gregory S. Cherry and John S. Clarke
}

\section{Abstract}

Steady-state simulations using a revised regional groundwater-flow model based on MODFLOW were run to assess the potential long-term effects on the Upper Floridan aquifer (UFA) of pumping the Lower Floridan aquifer (LFA) at well 36Q398, located at Barbour Pointe in coastal Georgia near Savannah. Simulated pumping of well 36Q398 at a rate of 750 gallons per minute (gal/min; or 1.08 million gallons per day $[\mathrm{Mgal} / \mathrm{d}]$ ) indicated a maximum drawdown of about 2.19 feet (ft) in the UFA directly above the pumped well and at least $1 \mathrm{ft}$ of drawdown within a nearly 190-square-mile area (scenario A). Induced vertical leakage from the UFA provided about 98 percent of the water to the pumped well. Simulated pumping of well 36Q398 caused increased downward leakage in all layers above the LFA, decreased upward leakage in all layers above the LFA, increased inflow to and decreased outflow from lateral specified-head boundaries in the UFA and LFA, and an increase in the volume of induced inflow from the general-head boundary representing outcrop units. Water budgets for scenario A indicated that changes in inflows and outflows through general-head boundaries would compose about 45 percent of the simulated pumpage from well 36Q398, with the remaining 55 percent of the pumped water derived from flow across lateral specified-head boundaries.

Additional steady-state simulations were run to evaluate a pumping rate in the UFA of $240 \mathrm{gal} / \mathrm{min}(0.346 \mathrm{Mgal} / \mathrm{d})$, which would produce an equivalent maximum drawdown in the UFA as pumping from well 36Q398 in the LFA at a rate of $750 \mathrm{gal} / \mathrm{min}$ (called the "drawdown offset"; scenario B). Simulated pumping in the UFA for the drawdown offset produced about $2.18 \mathrm{ft}$ of drawdown, comparable to $2.19 \mathrm{ft}$ of drawdown in the UFA simulated in scenario A. Water budgets for scenario B also provided favorable comparisons with scenario A, indicating that 42 percent of the drawdown-offset pumpage $(0.346 \mathrm{Mgal} / \mathrm{d})$ in the UFA originates as increased inflow and decreased outflow across general-head boundaries from overlying units in the surficial and Brunswick aquifer systems and that the remaining simulated pumpage originates as flow across general- and specified-head boundaries within the UFA and LFA.
The revised model was evaluated for sensitivity by first altering horizontal and vertical hydraulic conductivity in the Lower Floridan semiconfining unit and then adjusting horizontal and vertical hydraulic conductivity in the LFA to match the $35.6 \mathrm{ft}$ of drawdown at pumping well 36Q398. These adjustments also affected the maximum simulated drawdown in the UFA and the equivalent offset pumping in the UFA that would produce the same amount of drawdown. The maximum drawdown in the UFA ranged from 1.82 to $2.57 \mathrm{ft}$ and the equivalent offset pumping in the UFA ranged from 199 to $278 \mathrm{gal} / \mathrm{min}$.

The revised model reasonably depicts changes in groundwater levels resulting from pumping the LFA at Barbour Pointe at a rate of $750 \mathrm{gal} / \mathrm{min}$. Results are limited, however, by the same model assumptions and design as the original model, and placement of boundaries and type of boundary used exert the greatest control on overall groundwater flow and interaquifer leakage in the system. Simulation results have improved regional characterization of the Floridan aquifer system, which could be used by State officials in evaluating requests for groundwater withdrawal from the LFA.

\section{Introduction}

Barbour Pointe, one of several residential communities served by Consolidated Utilities LLC, in western Chatham County, Georgia (fig. 1), is experiencing increased demands on its limited freshwater resources. To alleviate the potential for saltwater intrusion in coastal Georgia, the Georgia Environmental Protection Division (GaEPD) has restricted further development of the Upper Floridan aquifer (UFA) in the Chatham County area and encouraged development of alternative water sources, such as the Lower Floridan aquifer (LFA; Georgia Department of Natural Resources, 2006).

Recent studies by the U.S. Geological Survey (USGS) at nearby Pooler, Ga., Hunter Army Airfield, Fort Stewart, and Rincon, Ga., evaluating the LFA as an alternate source of groundwater indicate that a strong interaquifer connection between the UFA and LFA exists in the Chatham County area and southern portion of Effingham County (Cherry and 

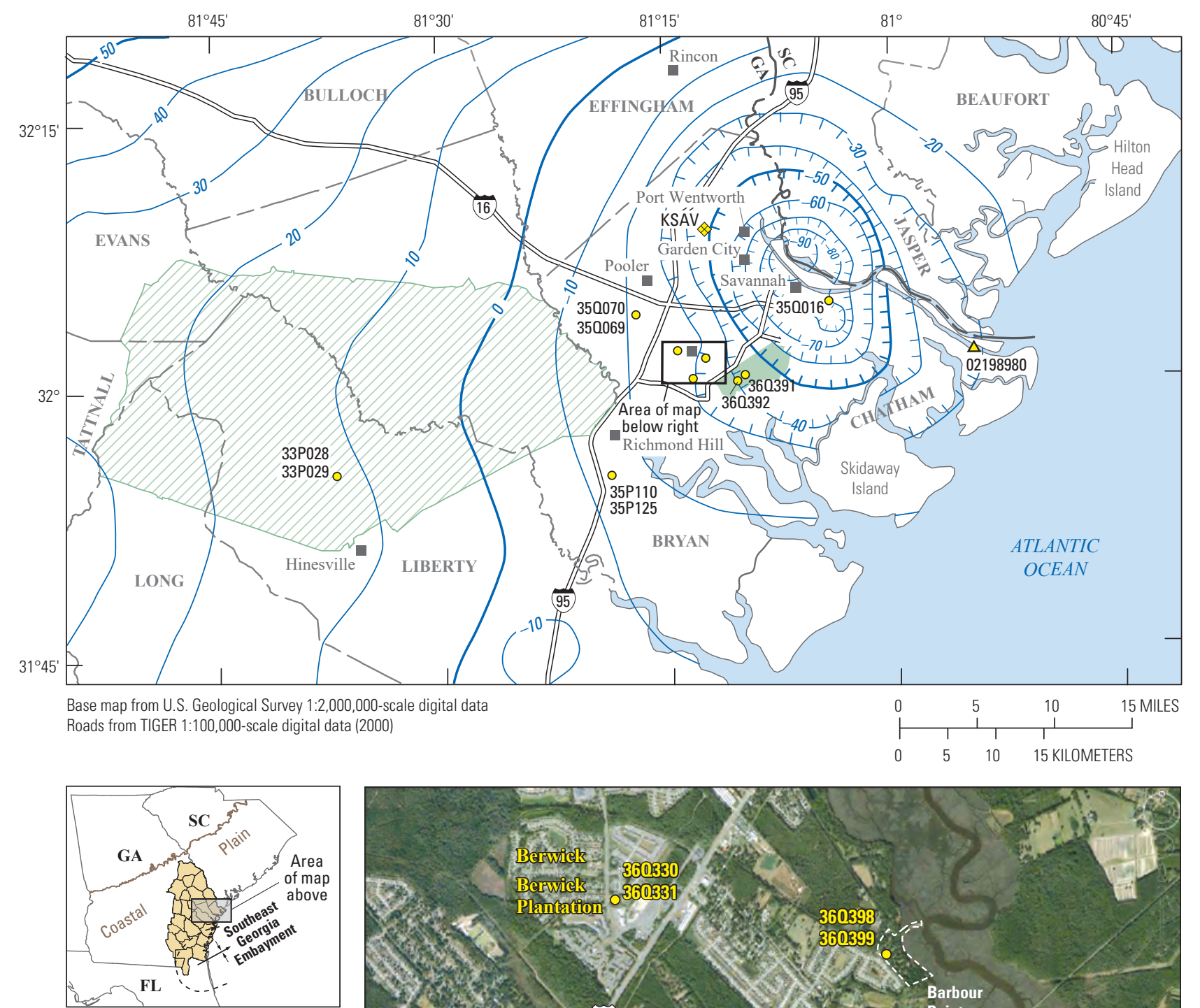

\section{EXPLANATION}

24-county coastal Georgia area as identified by the Georgia Environmental Protection Division

\section{Fort Stewart}

Hunter Army Airfield

- $0-$ Potentiometric contour May 1998Contour interval is 10 feet.

Hachures indicate depression. Datum is NAVD 88

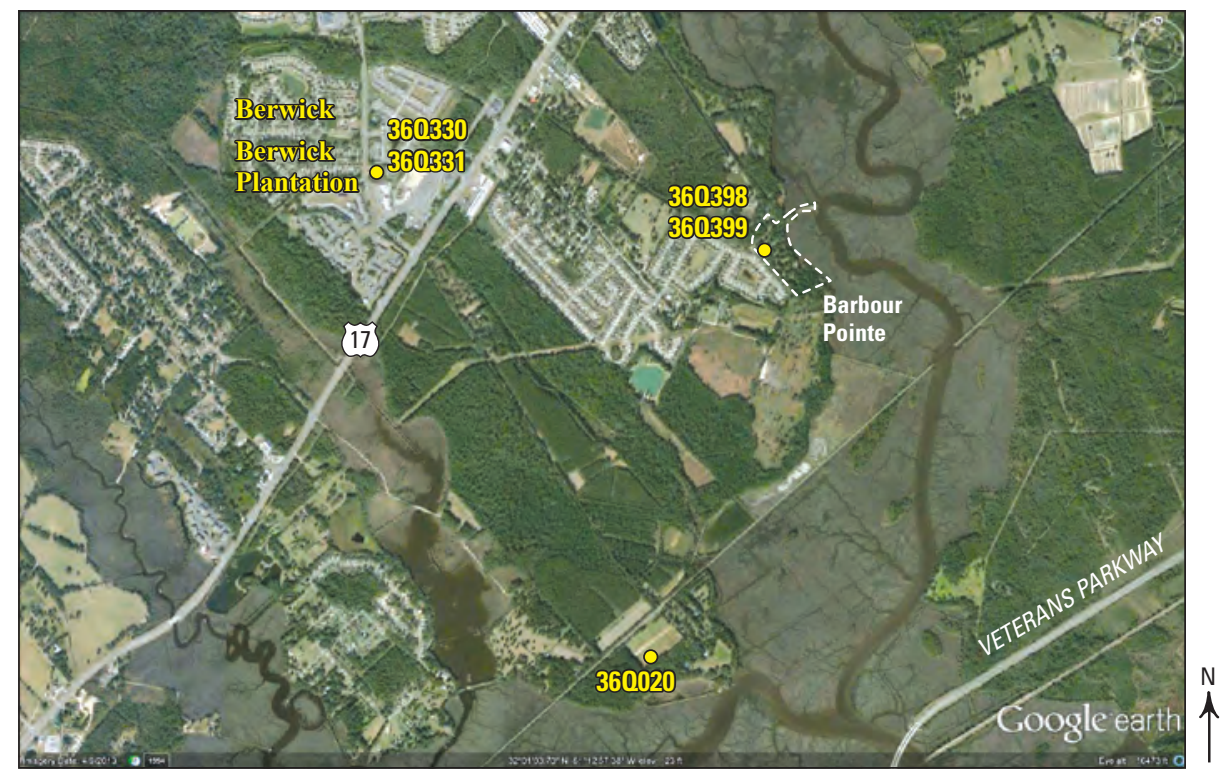

360330 ○ Well and identifier

$02198980 \triangle \quad$ Streamgage and identification number

$\mathrm{KSAV} \otimes$ Weather station and name

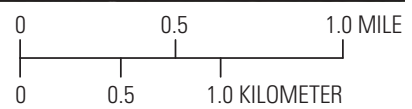

Figure 1. Barbour Pointe test site (wells 360398 and 360399), Chatham County, Georgia, and potentiometric surface of the Upper Floridan aquifer in coastal Georgia, 1998. 
Clarke, 2013, 2015; Clarke and others, 2010, 2011). As a result of these findings, GaEPD issued a policy statement on May 20, 2013, that stated the Floridan aquifer system (FAS) "is really one aquifer with hydraulically connected upper and lower permeable zones" (Georgia Department of Natural Resources, 2013). The lowermost of these zones has been designated the LFA by Williams and Gill (2010).

To assess the water-supply potential of the LFA, the USGS, in cooperation with Consolidated Utilities LLC, performed an investigation during 2013 to determine the hydrogeology and water quality of the FAS and the potential simulated interaquifer leakage from the UFA into the LFA caused by pumping from a new production well in the LFA. The study included construction of an LFA production well (36Q398) and UFA observation well (36Q399) and detailed site investigations (Gonthier and Clarke, 2016). Data from this investigation add to the USGS database of hydrogeologic information that collectively improves regional characterization of the FAS in the Southeast.

\section{Purpose and Scope}

This report documents the results of groundwater-model simulations completed at Barbour Pointe during 2013 to assess the effect of LFA pumping on the UFA, specifically, to

- evaluate the leakage response in a nearby well completed in the UFA (36Q399) to pumping from the LFA (36Q398), and

- quantify the reduction in pumping in a UFA well (or wells) that would offset leakage from the UFA into the LFA induced by pumping and mitigate drawdown in the UFA caused by pumping in the LFA.

Model simulations were completed using a modified version of a regional groundwater-flow model of coastal Georgia covering 42,155 square miles $\left(\mathrm{mi}^{2}\right)$ in Georgia and adjacent areas in South Carolina and Florida (fig. 1-1; Payne and others, 2005). The 2005 report includes maps showing drawdown response to pumping, ZONEBUDGET (Harbaugh, 1990) analysis of interaquifer and boundary flow, and a comparison of simulation results to the original model of Payne and others (2005). All data input files and corresponding output are provided in Cherry (2017).

\section{Previous Studies}

Jordan, Jones, and Goulding, Inc. (2002) completed detailed field studies at nearby Berwick Plantation at Berwick that included construction of an LFA test well (36Q330), collection of geophysical and flowmeter logs (by the USGS), water sampling, and completion of an 8-hour UFA test and 72-hour LFA test. The report included some preliminary groundwater model simulations.

The USGS completed several comprehensive field and modeling studies of the FAS in coastal Georgia. These include Hunter Army Airfield (Clarke and others, 2010; Williams, 2010), Fort Stewart (Clarke and others, 2011; Gonthier, 2011), Pooler (Cherry and Clarke, 2013; Gonthier, 2012), and Rincon (Cherry and Clarke, 2015; Carter and Sloope, 2004). The scope of these investigations included field testing and groundwater-model simulations to determine the hydrogeology and water quality of the FAS and to provide data needed to assess the effect of LFA pumping on the UFA. The method of study for the Barbour Pointe test site is similar to the earlier investigations at Hunter Army Airfield, Fort Stewart, and the city of Pooler. Field investigations consisted of

- boring a test hole and constructing a test well completed in the LFA,

- collecting drill cuttings and borehole geophysical logs at the test well,

- completing flowmeter surveys through the entire length of the FAS in the open test hole and in the completed LFA well,

- collecting depth-integrated water samples to assess water quality of various water-bearing zones,

- boring and constructing an observation well completed in the UFA, and

- completing a 72-hour aquifer test at the test well open to the LFA while monitoring water levels in both the LFA and UFA test wells.

The other three studies also included the collection of cores for hydraulic analysis and completing packer slug tests within the Lower Floridan semiconfining unit (LFCU); however, the current investigation did not complete these tests owing to cost limitations. Results of field investigations at the Barbour Pointe site are provided in Gonthier and Clarke (2016). In addition to field investigations, the method applied for model simulations at Hunter Army Airfield, Fort Stewart, Pooler, and Rincon was identical to that applied to the Barbour Pointe study, with modifications similar to those of the regional model of Payne and others (2005). Collectively, data obtained from these investigations add to the body of knowledge needed to characterize the FAS on a regional scale.

Miller (1986) developed a hydrogeologic framework for the FAS throughout its extent in Georgia, Florida, South Carolina, and Alabama. This framework was subsequently revised by Williams and Gill (2010) for 8 northern coastal counties in Georgia and 5 coastal counties in South Carolina, including the area of the Barbour Pointe test site and test sites at Hunter Army Airfield, Fort Stewart, Pooler, and Rincon. Williams and Kuniansky (2015) further revised the framework of the aquifer system in all four States. The Williams and Gill (2010) and Williams and Kuniansky (2015) studies used borehole geophysical and flowmeter log data collected since the original study of Miller 
(1986) to shift the position of internal boundaries of the UFA and LFA and of the individual permeable zones that compose these aquifers. These revised boundaries, but not the nomenclature, were used to guide projected drilling depths at the Barbour Pointe site.

\section{Site Description}

Barbour Pointe is located in the Coastal Plain physiographic province in west-central Chatham County, Ga., near Interstate 95 (fig. 1). The site is characterized by low-altitude, flat topography and sandy topsoil, typical of the Georgia coastal area. A new LFA production well (36Q398) was constructed at the site, and a new UFA observation well (36Q399) was installed about 40 feet (ft) to the north. The LFA well 36Q398 is located at an altitude of about $5 \mathrm{ft}$ above the North American Vertical Datum of 1988 (NAVD 88) with static (non-pumping) water levels in the UFA at an altitude of about $-30 \mathrm{ft}$, or a depth of $35 \mathrm{ft}$ below land surface during May 1998 (Peck and others, 1999).

The study area has a mild climate with warm, humid summers and mild winters. Long-term climatic patterns in the area are derived from records provided by the National Weather Service Station at Savannah International Airport (climatological station 097847, labeled "KSAV" on fig. 1; Southeast Regional Climate Center, 2011). During 1971-2000, precipitation at station 097847 averaged about 49.6 inches per year. Maximum monthly rainfall (exceeding 4 inches per month) generally occurs during January and June-September, with monthly rainfall totals averaging less than 4 inches during the rest of the year. Mean monthly pan evaporation at station 097847 during 1965-2003 ranged from 2.43 to 8.49 inches per month, with the greatest evaporation occurring during April-August (Southeast Regional Climate Center, 2011).

\section{Water Use}

Water supply for the nearby city of Berwick (Consolidated Utilities LLC) is provided by 4 wells completed in the UFA, 1 well completed in the LFA, and 3 wells completed in the Brunswick aquifer system. Because of concern about saltwater intrusion, the GaEPD has implemented restrictions on groundwater withdrawals from the UFA and designated management zones in coastal Georgia. Barbour Pointe is located in the GaEPD "red zone," where withdrawal from the UFA is capped at the 2004 pumping rate. The GaEPD water-withdrawal permit for the city of Berwick allows an annual daily average withdrawal of 0.309 million gallons per day (Mgal/d) for the UFA (Jeff Larson, Georgia Environmental Protection Division, written commun., 2008), 0.525 Mgal/d for the LFA (Christine Voudy, Georgia Environmental Protection Division, written commun., 2003), and $2 \mathrm{Mgal} / \mathrm{d}$ for the Brunswick aquifer system (William Frechette, Georgia Environmental Protection Division, written commun., 2013).
Groundwater use in Chatham County totaled $54.6 \mathrm{Mgal} / \mathrm{d}$ during 2010 (Steven J. Lawrence, U.S. Geological Survey, written commun., 2013). Nearly 60 percent of this use, or $32.0 \mathrm{Mgal} / \mathrm{d}$, was for public supply. Most production wells are located in the city of Savannah; additional wells to the northwest serve Pooler and to the northeast serve Garden City and Port Wentworth (fig. 1; Fanning and Trent, 2009). Payne and others (2005) estimated that during 1980-2000, nearly 95 percent of groundwater withdrawn in Chatham County was pumped from the UFA; the remaining 5 percent was derived from the LFA. Groundwater withdrawals from the FAS in the county decreased from $68.2 \mathrm{Mgal} / \mathrm{d}$ in 2000 to $54.6 \mathrm{Mgal} / \mathrm{d}$ in 2010 .

\section{Hydrogeologic Setting}

Chatham County (fig. 1) is underlain by Coastal Plain strata consisting of consolidated to unconsolidated layers of sand and clay and semiconsolidated to very dense layers of limestone and dolomite (Miller, 1986; Clarke and others, 1990; Williams and Gill, 2010; Williams and Kuniansky, 2015). These sediments constitute three major aquifer systems, which are, in descending order, the surficial aquifer system, Brunswick aquifer system, and FAS (fig. 2).

In coastal Georgia, the surficial aquifer system consists of Miocene and younger interlayered sand, clay, and thin limestone beds (Clarke, 2003). At Barbour Pointe, the surficial aquifer system consists of fine- to coarse-grained sand, clay, and marl at depths of less than $70 \mathrm{ft}$ and largely is unconfined. Elsewhere in coastal Georgia, the surficial aquifer system includes a water-table zone and two confined water-bearing zones; however, the areal extent of the confined water-bearing zones is unknown (Clarke, 2003). The surficial aquifer system is separated from the underlying Brunswick aquifer system by a confining unit consisting of silty clay and dense, phosphatic Miocene limestone.

The Oligocene to Miocene Brunswick aquifer system consists of two water-bearing zones - the upper Brunswick aquifer and the lower Brunswick aquifer (Clarke, 2003). The upper Brunswick aquifer consists of poorly sorted, fine- to coarse-grained, slightly phosphatic and dolomitic quartz sand, and dense, phosphatic limestone (Clarke and others, 1990). The lower Brunswick aquifer consists of poorly sorted, fine- to coarse-grained, phosphatic and dolomitic Oligocene and Miocene sand (Clarke and others, 1990). At Barbour Pointe, Miocene sediments equivalent to the Brunswick aquifer system are present between depths of 67 and $280 \mathrm{ft}$, and consist largely of low permeability, clayey fine sand and silt, with slightly higher permeability between depths of 246 and $280 \mathrm{ft}$. 


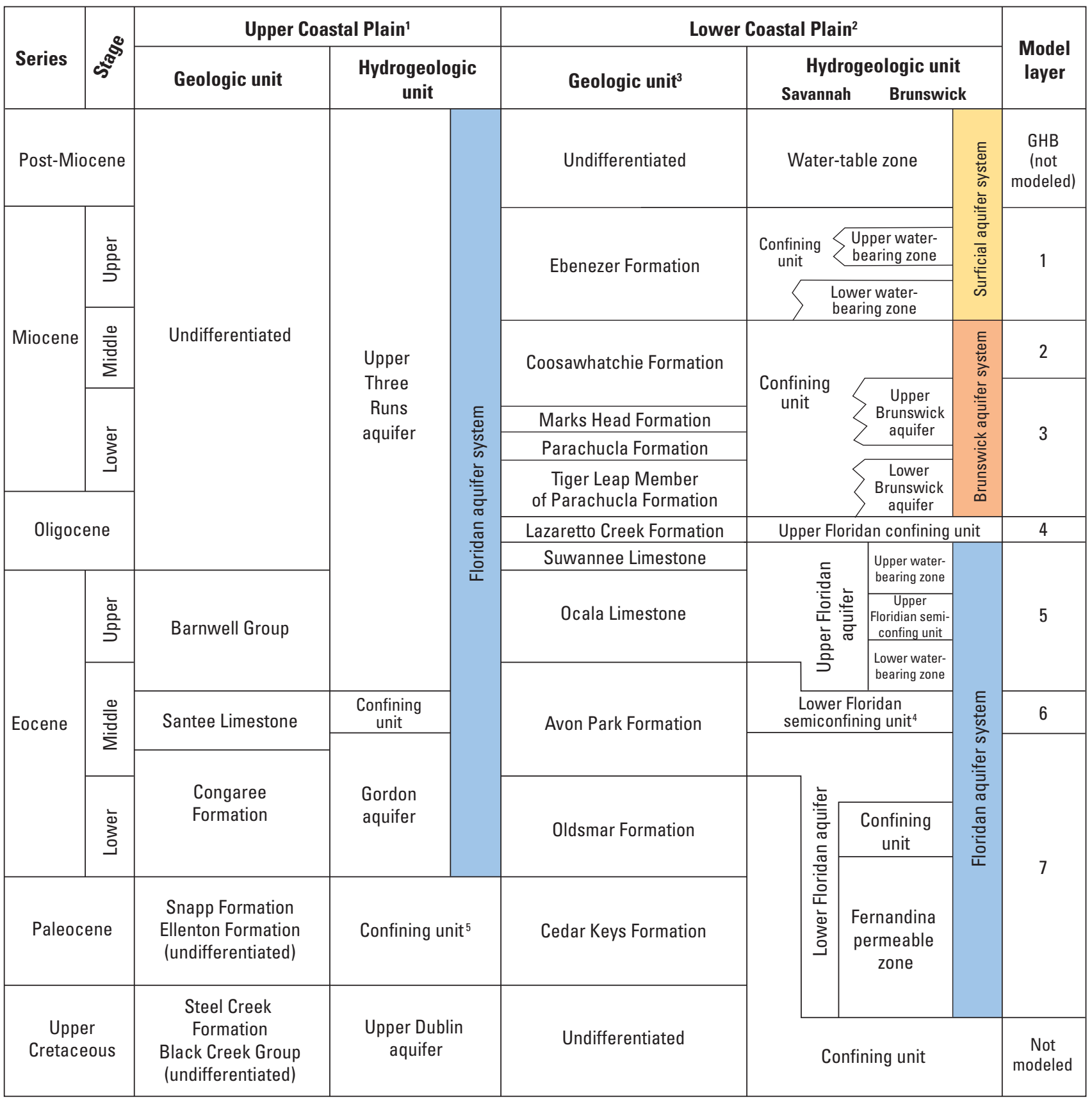

'Modified from Falls and others, 1997.

${ }^{2}$ Modified from Randolph and others, 1991; Clarke and Krause, 2000

${ }^{3}$ Modified from Randolph and others, 1991; Weems and Edwards, 2001.

${ }^{4}$ Middle confining unit 1 in Miller (1986); middle confining unit in Williams and

Gill (2010); Lisbon-Avon Park composite unit in Williams and Kuniansky (2015).

In local areas includes Millers Pond aquifer.

Figure 2. Generalized correlation chart showing geologic and hydrogeologic units and model layers in the Coastal Plain of Georgia (modified from Payne and others, 2005). [GHB, general head boundary]. 
The principal source of water for all uses (excluding thermoelectric) in the coastal area of Georgia is the FAS, which is the subject of this report. The FAS is confined by overlying clay layers and is separated into several permeable, water-bearing zones by layers of dense limestone or dolomite that act as semiconfining units. In the coastal area, the system has been subdivided by the USGS into the UFA and LFA (Miller, 1986; Williams and Gill, 2010; Williams and Kuniansky, 2015).

Williams and Gill (2010) provided an updated hydrogeologic framework for the northern coastal area of Georgia and adjacent part of South Carolina. Using information from that report and new data collected at Barbour Pointe, the UFA and LFA, as defined by the USGS, are present at the following depths at the Barbour Pointe well site:

- Top UFA: $300 \mathrm{ft}$

- Base UFA: $567 \mathrm{ft}$

- Top LFA: $714 \mathrm{ft}$

- Base of LFA: 1,050 ft

Results of flowmeter testing in the Barbour Pointe well indicate there are three principal water-bearing zones in the UFA present at depths of: $364-400 \mathrm{ft}, 421-456 \mathrm{ft}$, and $482-560 \mathrm{ft}$ (fig. 3; Gonthier and Clarke, 2016). The calculated transmissivity from a 24-hour aquifer test of the UFA was 60,000 feet squared per day ( $\mathrm{ft}^{2} / \mathrm{d}$; Gonthier and Clarke, 2016).

The UFA and LFA are separated by a leaky semiconfining unit consisting of chalky and glauconitic limestone in the uppermost part of the middle Eocene Avon Park Formation, extending from 567 to $714 \mathrm{ft}$ at Barbour Pointe (fig. 3; Gonthier and Clarke, 2016). This leaky unit is called "middle confining unit I" in Miller (1986); "lower Floridan confining unit" in Payne and others (2005); "middle confining unit" in Williams and Gill (2010); and "Lisbon-Avon Park composite unit" in Williams and Kuniansky (2015). In this report, the leaky semiconfining unit is referred to as the "lower Floridan semiconfining unit" (LFCU). The thickness and hydraulic conductivity of the LFCU control the rate of interaquifer leakage between the UFA and LFA. Results of a flowmeter survey indicate that the LFCU contributes little to the overall flow in a test hole open to the entire FAS, and a single water-bearing zone is present between depths of 700 and $719 \mathrm{ft}$, yielding 7 gallons per minute ( $\mathrm{gal} / \mathrm{min}$ ). Hydraulic properties of the LFCU were not measured at Barbour Pointe; however, they were characterized at the nearby Pooler and Hunter Army Airfield sites (Williams, 2010; Gonthier, 2012). Slug tests and core samples were analyzed for selected intervals within the LFCU at each of the two sites. At Hunter Army Airfield, the estimated vertical hydraulic conductivity $\left(\mathrm{K}_{\mathrm{v}}\right)$ ranged from 0.02 to 0.36 foot per day $(\mathrm{ft} / \mathrm{d})$, with a median of $0.075 \mathrm{ft} / \mathrm{d}$ (Williams, 2010). At Pooler, estimated $\mathrm{K}_{\mathrm{v}}$ ranged from 0.05 to $1.67 \mathrm{ft} / \mathrm{d}$, with a median of $0.79 \mathrm{ft} / \mathrm{d}$. The median of all values at the two sites was $0.33 \mathrm{ft} / \mathrm{d}$, which indicates the LFCU is not fully confining.

The LFA consists of chalky and glauconitic limestone in the upper part of the middle Eocene Avon Park Formation, which is similar in lithology to overlying units. The depth interval of the LFA was generally consistent in the
Barbour Pointe area with greater thickness towards the north near the Rincon area (table 1). The observed drawdown in the UFA resulting from pumping the LFA was $4.5 \mathrm{ft}$ at Rincon (Carter and Sloope, 2004) and ranged from 0.37 to $0.8 \mathrm{ft}$ at the other four sites, which includes Barbour Pointe. Results of flowmeter testing at Barbour Pointe identified four waterbearing depth intervals within the LFA: 753 to $770 \mathrm{ft}, 783$ to $796 \mathrm{ft}, 870$ to $940 \mathrm{ft}$, and 1,023 to $1,050 \mathrm{ft}$ (fig. 3; Gonthier and Clarke, 2016). No flow was detected below a depth of $1,050 \mathrm{ft}$ where the lower confining unit is present. The transmissivity of the LFA is 5,100 $\mathrm{ft}^{2} / \mathrm{d}$ at Barbour Pointe (Gonthier and Clarke, 2016), compared to $4,000 \mathrm{ft}^{2} / \mathrm{d}$ at Pooler (Gonthier, 2012) and 10,700 $\mathrm{ft}^{2} / \mathrm{d}$ at Hunter Army Airfield (Williams, 2010).

\section{Groundwater Flow}

Groundwater flow in the FAS is determined by the rate and distribution of recharge to and discharge from the system, the extent and effectiveness of confinement, and the ability of aquifers to transmit and store water (Krause and Randolph, 1989). The conceptualized predevelopment (no pumping) and modern-day (2000) groundwater-flow systems in coastal Georgia (fig. 4) receive water from precipitation and downward leakage through shallow geologic units that recharge the aquifers in the northern part of the coastal area where the units are exposed at or near land surface. Groundwater then flows mostly southeastward toward the coast, where it discharges into overlying units and surface-water bodies. Prior to development, the flow system was considered to be in dynamic equilibrium, where recharge balances discharge, and potentiometric surfaces were considered nearly static from year to year. Generally, predevelopment potentiometric surfaces were higher than current groundwater levels, and test wells tapping the FAS flowed at the surface along the coast (fig. $4 A$ ).

The modern-day (2000) flow system reflects changes that have occurred as a result of groundwater development (withdrawals; fig. 4B). Groundwater withdrawals have lowered potentiometric heads in the UFA, induced additional recharge from vertical leakage and regional flow, reduced natural discharge, and degraded the quality of water locally along the coast. Groundwater pumping has caused an extensive cone of depression to develop in the potentiometric surface of the UFA in the Savannah area (fig. 1). This feature has affected groundwater flow near Barbour Pointe, as evidenced by the shape of potentiometric contours, indicating groundwater flow is toward the center of the cone of depression.

Saltwater contamination restricts development of the groundwater supply in coastal Georgia and adjacent parts of South Carolina and Florida (Krause and Clarke, 2001). Pumping from the UFA has resulted in substantial groundwaterlevel decline and subsequent saltwater intrusion into the UFA at Brunswick, Ga., from underlying strata containing highly saline water and the encroachment of seawater into the UFA at the northern end of Hilton Head Island, S.C. Saltwater contamination at these locations has constrained further development of the UFA in the coastal area and has created competing demands for the limited supply of freshwater. 


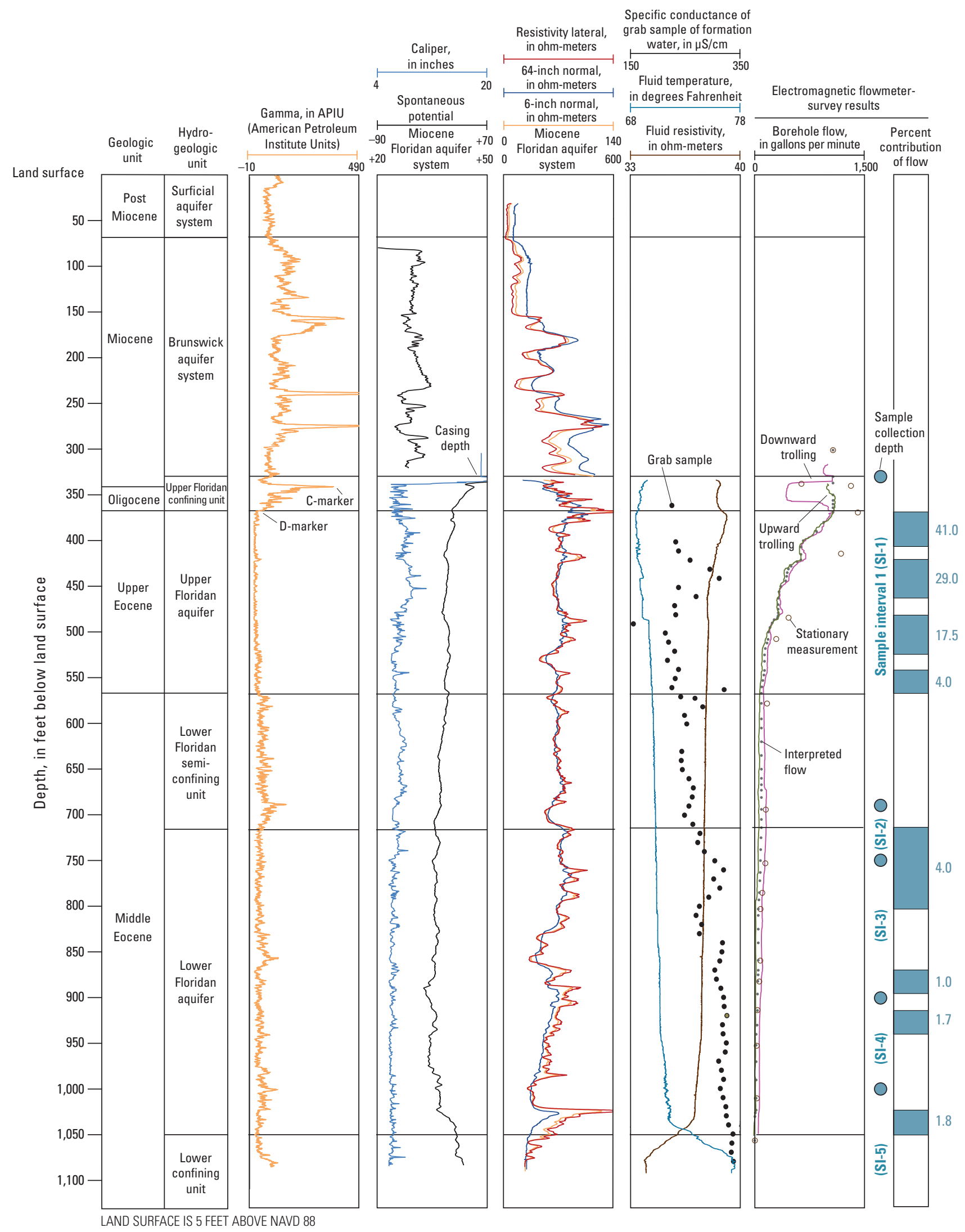

Figure 3. Geophysical properties, electromagnetic flowmeter survey, and specific conductance of discharging formation water, test hole for Lower Floridan aquifer well 360398, Barbour Pointe, Chatham County, Georgia. $[\mu \mathrm{S} / \mathrm{cm}$, microsiemens per centimeter at 25 degrees Celsius]. 
Table 1. Summary of data collected at sites in the Lower Floridan aquifer in coastal Georgia.

[HAAF, Hunter Army Airfield; LFA, Lower Floridan aquifer; UFA, Upper Floridan aquifer]

\begin{tabular}{|c|c|c|c|c|c|}
\hline Property & $\begin{array}{c}\text { Rincon } \\
\text { (well 36S048) }\end{array}$ & $\begin{array}{c}\text { Pooler } \\
\text { (well 350069) }\end{array}$ & $\begin{array}{c}\text { Berwick } \\
\text { (well 360330) }\end{array}$ & $\begin{array}{l}\text { Barbour Pointe } \\
\text { (well 360398) }\end{array}$ & $\begin{array}{c}\text { HAAF } \\
\text { (well 360392) }\end{array}$ \\
\hline LFA depth interval (feet) & $565-1,000$ & $702-1,040$ & $700-1,080$ & $714-1,050$ & $703-1,080$ \\
\hline $\begin{array}{l}\text { LFA specific capacity (gallons per minute per foot of } \\
\text { drawdown) }\end{array}$ & 13.8 & 15 & 23.1 & 21.1 & 20.8 \\
\hline $\begin{array}{l}\text { Maximum drawdown UFA (resulting from LFA pumping, } \\
\text { in feet) }\end{array}$ & 4.5 & 0.8 & 0.37 & 0.71 & 0.76 \\
\hline
\end{tabular}

\section{A. Predevelopment}

NORTHWEST

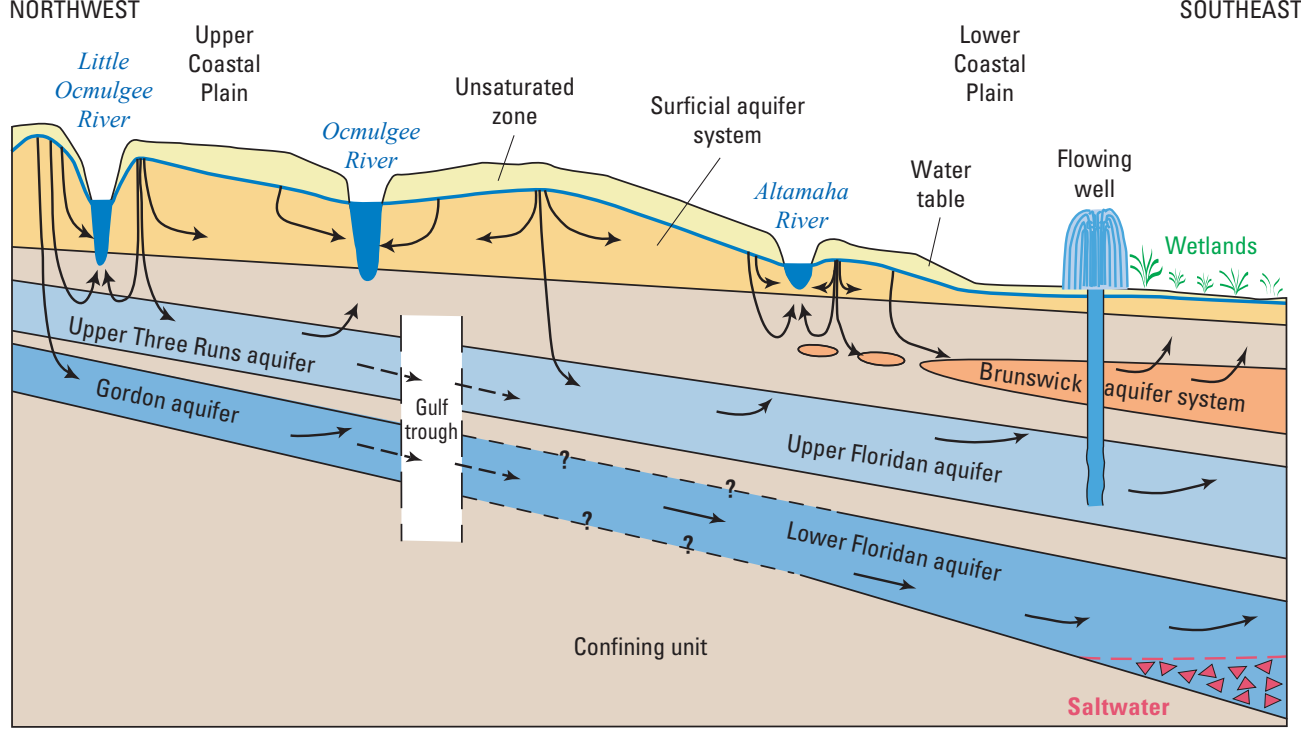

NOT TO SCALE

\section{B. Modern day}

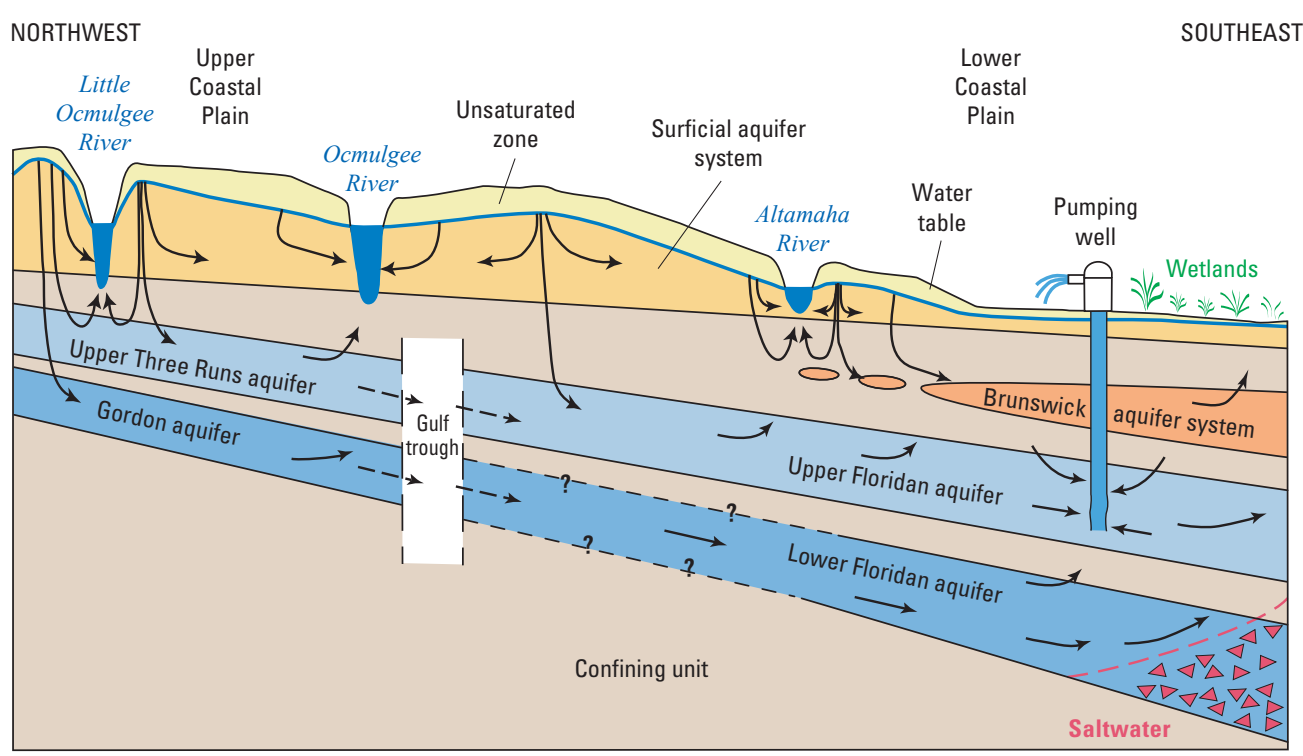

NOT TO SCALE

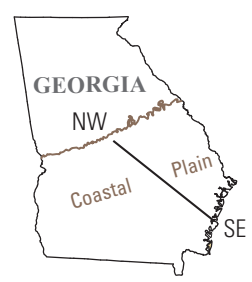

Figure 4. Schematic diagram showing conceptual model of, $A$, predevelopment and, $B$, modern-day (2000) flow system. Arrows indicate general direction of groundwater flow (modified from Priest, 2004; Payne and others, 2005). 


\section{Well Identification}

In this report, wells are named by means of a local USGS numbering system that is based on the index of USGS topographic maps (such as 36Q398). In Georgia, each 7.5-minute topographic quadrangle map has been given a number and letter designation beginning at the southwestern corner of the State. Numbers increase eastward through 39, and letters increase alphabetically northward through " $\mathrm{Z}$ " and then become double-letter designations "AA" through "PP." The letters "I" and "O" are not used. Wells inventoried in each quadrangle are numbered sequentially beginning with "1." For example, well 36Q398 is the 398th well inventoried in the Garden City quadrangle (map 36Q).

\section{Simulated Effect of Lower Floridan Aquifer Pumping on the Upper Floridan Aquifer}

The potential effects of pumping the LFA on water levels in the UFA were evaluated by monitoring drawdown response in nearby UFA wells and through model simulation. Observed water-level response in the UFA as a result of pumping the LFA was determined by using water-level data that were filtered for tidal, barometric, and pumping interferences (Gonthier and Clarke, 2016). These measured drawdowns provided a basis for evaluating the accuracy of model simulations. These simulations were used to determine long-term (steady-state) leakage response of the UFA to pumping from the LFA, and to estimate the equivalent amount of UFA pumping that would produce similar drawdown.

\section{Observed Water-Level Response}

The LFA well 36Q398 was pumped at a rate of $750 \mathrm{gal} / \mathrm{min}$ for a 72-hour period during November 19-22, 2013. In this study, the same pumping rate of $750 \mathrm{gal} / \mathrm{min}$ was used to simulate drawdown in the UFA and LFA. Filtering of water-level data using the spreadsheet procedure of Halford (2006) isolated the drawdown response from unrelated natural and anthropogenic controls, such as tidal, barometric, and regional pumping influences (Gonthier and Clarke, 2016). The filtering yielded synthesized water levels that presumably reflect drawdown caused only by pumping of LFA well 36Q398 (fig. 5A, $B$ ). These synthesized water levels indicated drawdown was $0.7 \mathrm{ft}$ in UFA well 36Q399 (fig. $6 B$ ) and $35.5 \mathrm{ft}$ in LFA well 36Q398 (fig. 5B; Gonthier and Clarke, 2016).

Drawdown in the LFA was nearly stable, whereas drawdown in the UFA continued to decline at the end of the 72-hour test period (figs. 5 and 6). Hypothetical water levels using the Theis solution provide a relatively good fit to the estimated drawdown in both wells. Because test pumping at LFA well 36Q398 was discontinued before drawdown had stabilized in the UFA, model simulation was used to determine long-term, steady-state effects on the FAS beyond the aquifer-test period. Simulations by Payne and others (2005) in coastal Georgia indicate that it could take 5 years or more to reach a steady-state condition in the Chatham County area. Because a 5-year-long aquifer test is impractical, model simulation provided a means to estimate the long-term steady-state condition.

\section{Model Simulation}

The groundwater-flow model was used to simulate requirements described in the GaEPD interim strategy for permitting LFA groundwater withdrawals in the 24-county coastal Georgia area (fig. 1; Nolton Johnston, Georgia Environmental Protection Division, written commun., 2003). Stipulations include (1) quantifying interaquifer leakage from the UFA to the LFA resulting from pumping the new LFA well and (2) calculating "the equivalent Upper Floridan pumping that induces the identical maximum drawdown in the Upper Floridan that would be expected as a result of pumping the Lower Floridan."

To comply with the GaEPD stipulations, the regional groundwater-flow model of Payne and others (2005) was modified to increase the spatial resolution and incorporate hydrogeologic information obtained from field investigations at Barbour Pointe (described earlier) and from nearby existing wells, as described in appendix 1. Simulations to evaluate the effects of pumping LFA well 36Q398 on groundwater levels and interaquifer leakage in the FAS were run using the revised model, which incorporated average pumping rates during 2010 in the city of Berwick wells and pumping rates during 2000 elsewhere as a base case for the evaluations.

Simulations of the following groundwater-model scenarios were used to quantify the long-term response of the FAS to changes in groundwater pumping in both the UFA and LFA (table 2):

- Scenario A-Steady-state simulation with LFA well 36Q398 pumping at a rate of $750 \mathrm{gal} / \mathrm{min}$, approximately same rate used during the 72 -hour aquifer test.

- Scenario B-Steady-state simulation with UFA well 36Q399 pumping at a rate $240 \mathrm{gal} / \mathrm{min}$, which would produce the same amount of drawdown as that resulting from pumping LFA well 36Q398 at a rate of $750 \mathrm{gal} / \mathrm{min}$ (simulated for scenario A). Several model runs were performed on a trial-anderror basis to achieve a drawdown match. 


\section{A. Synthetic and measured water levels}

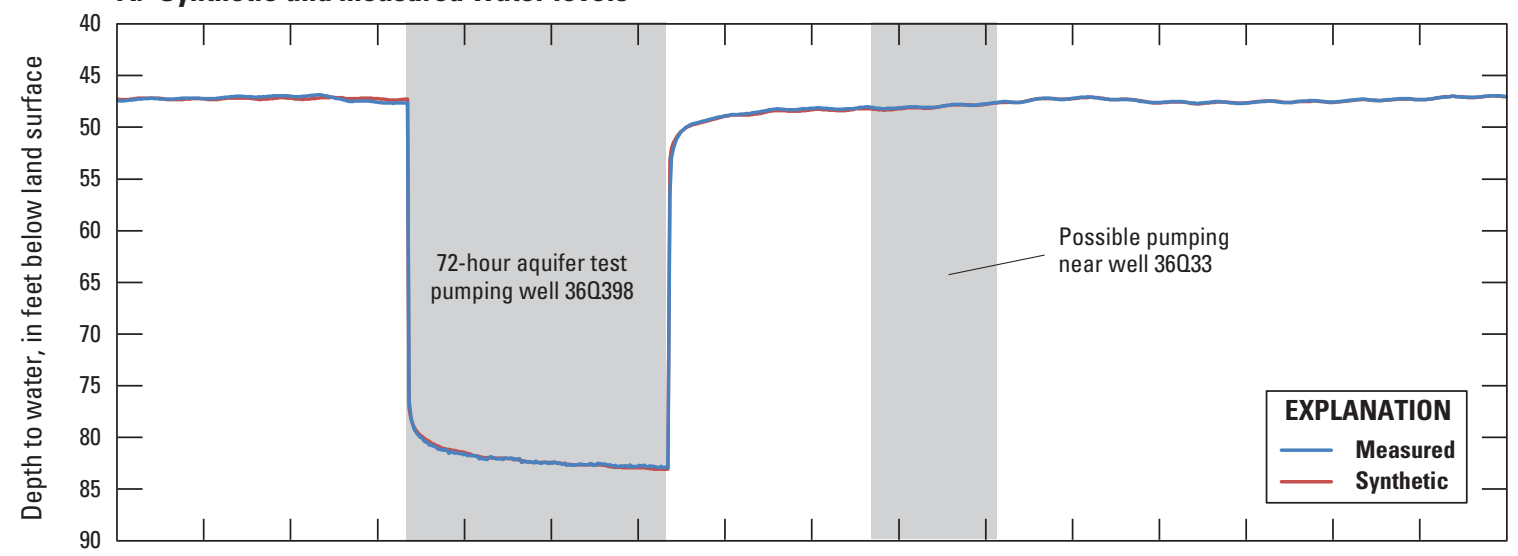

\section{B. Estimating drawdown}

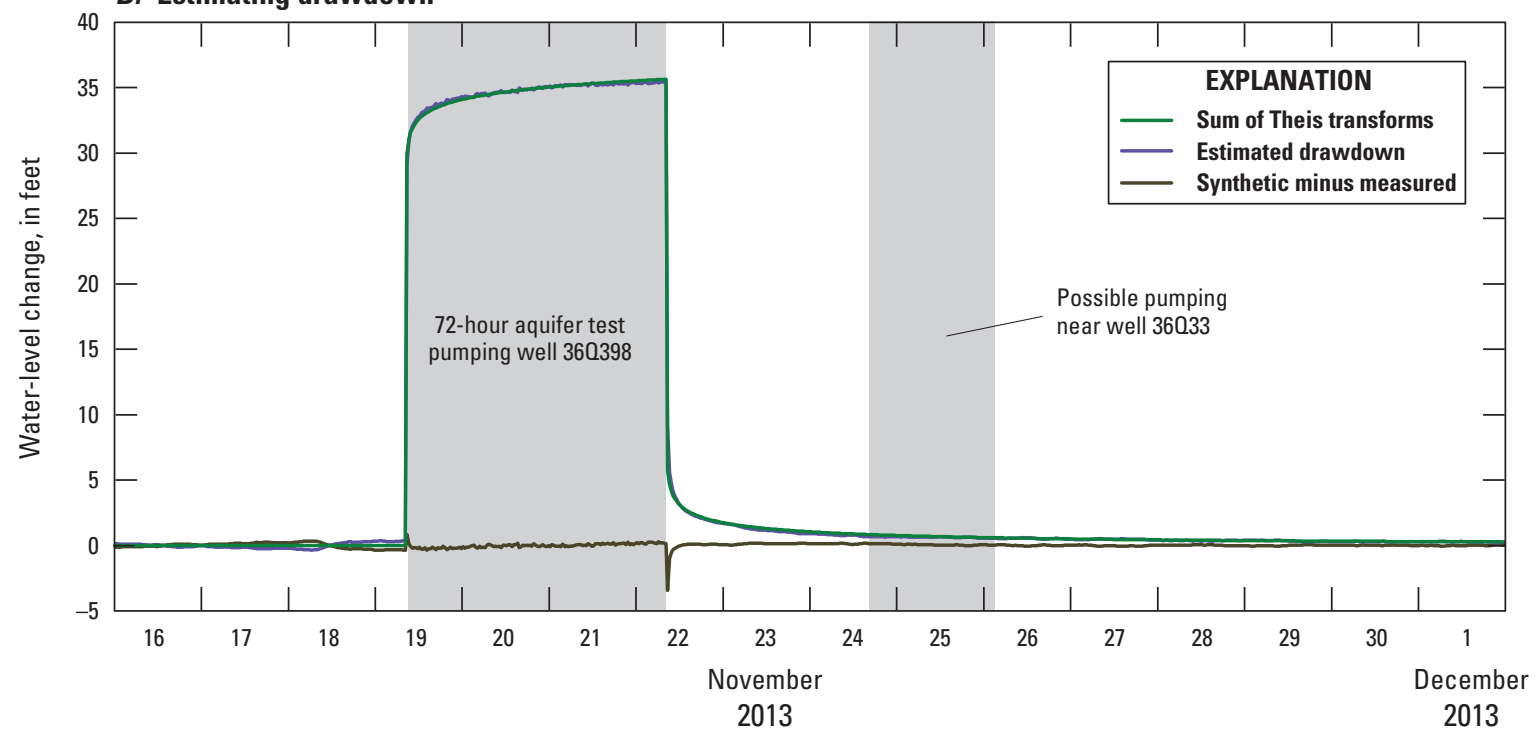

Figure 5. Fit of synthetic water levels to measured water levels for Lower Floridan aquifer pumped well 360398, Barbour Pointe, Georgia, November 16-December 1, 2013. A, Synthetic and measured water levels, and $B$, Sum of Theis transforms, estimated drawdown, and synthetic water level minus the measured water level. Modified from Gonthier and Clarke (2016). 


\section{A. Synthetic and measured water levels}

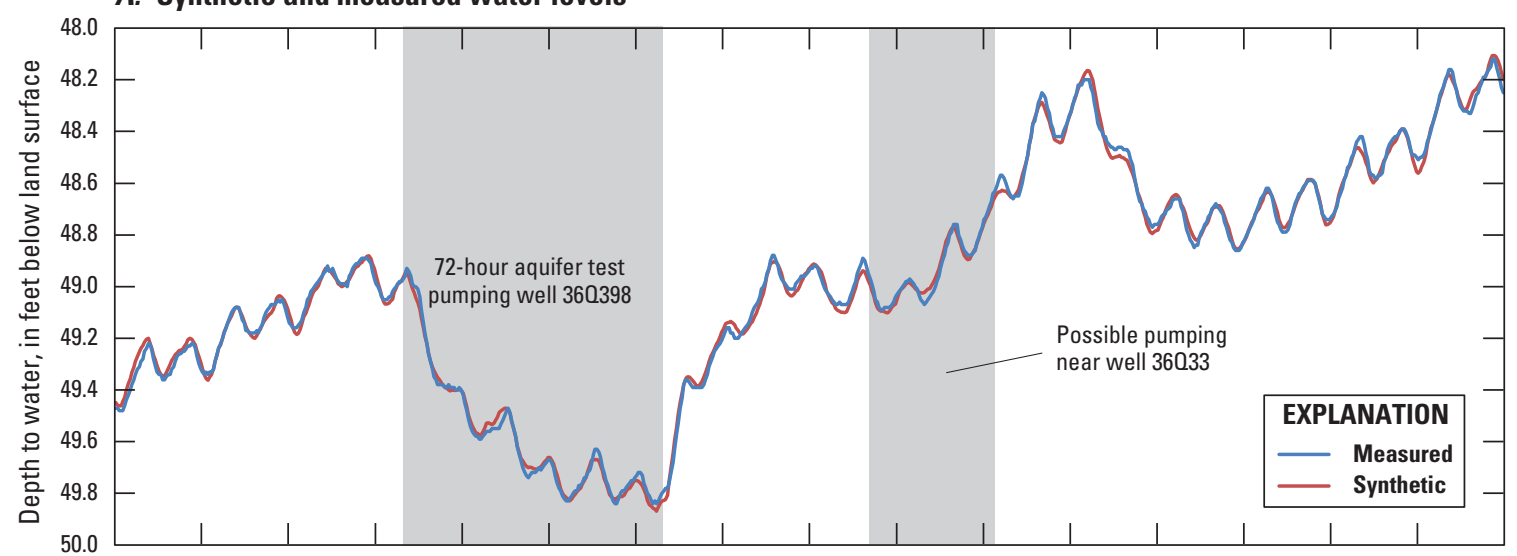

\section{B. Estimating drawdown}

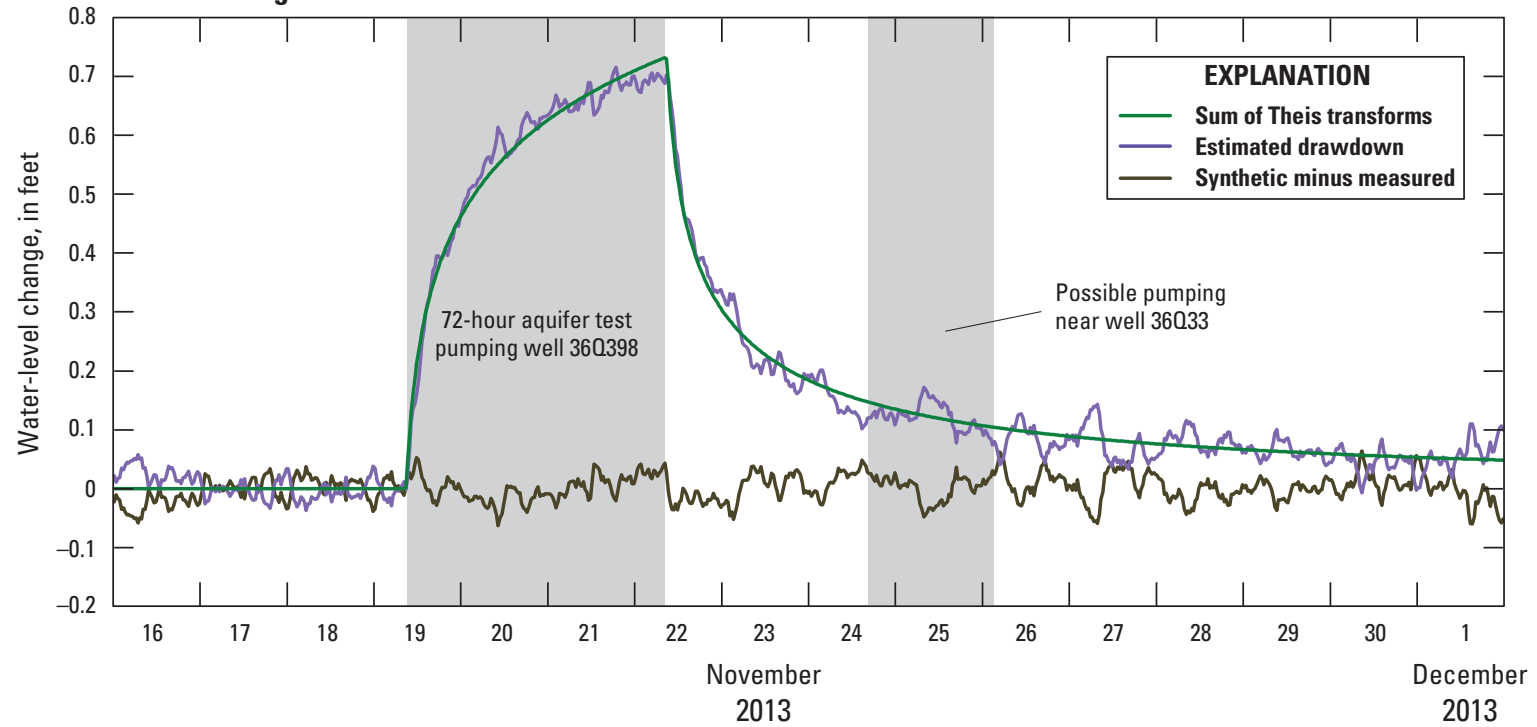

Figure 6. Fit of synthetic water levels to measured water levels for Upper Floridan aquifer well 360399, Barbour Pointe, Georgia, November 16-December 1, 2013. A, Synthetic and measured water levels, and $B$, Sum of Theis transforms, estimated drawdown, and the synthetic water level minus the measured water level. Modified from Gonthier and Clarke (2016). 
Table 2. Description of model scenarios and simulated drawdown in the Upper and Lower Floridan aquifers for various pumping distributions at Barbour Pointe, Georgia.

[LFA, Lower Floridan aquifer ; UFA, Upper Floridan aquifer; gal/min, gallon per minute; — , not applicable]

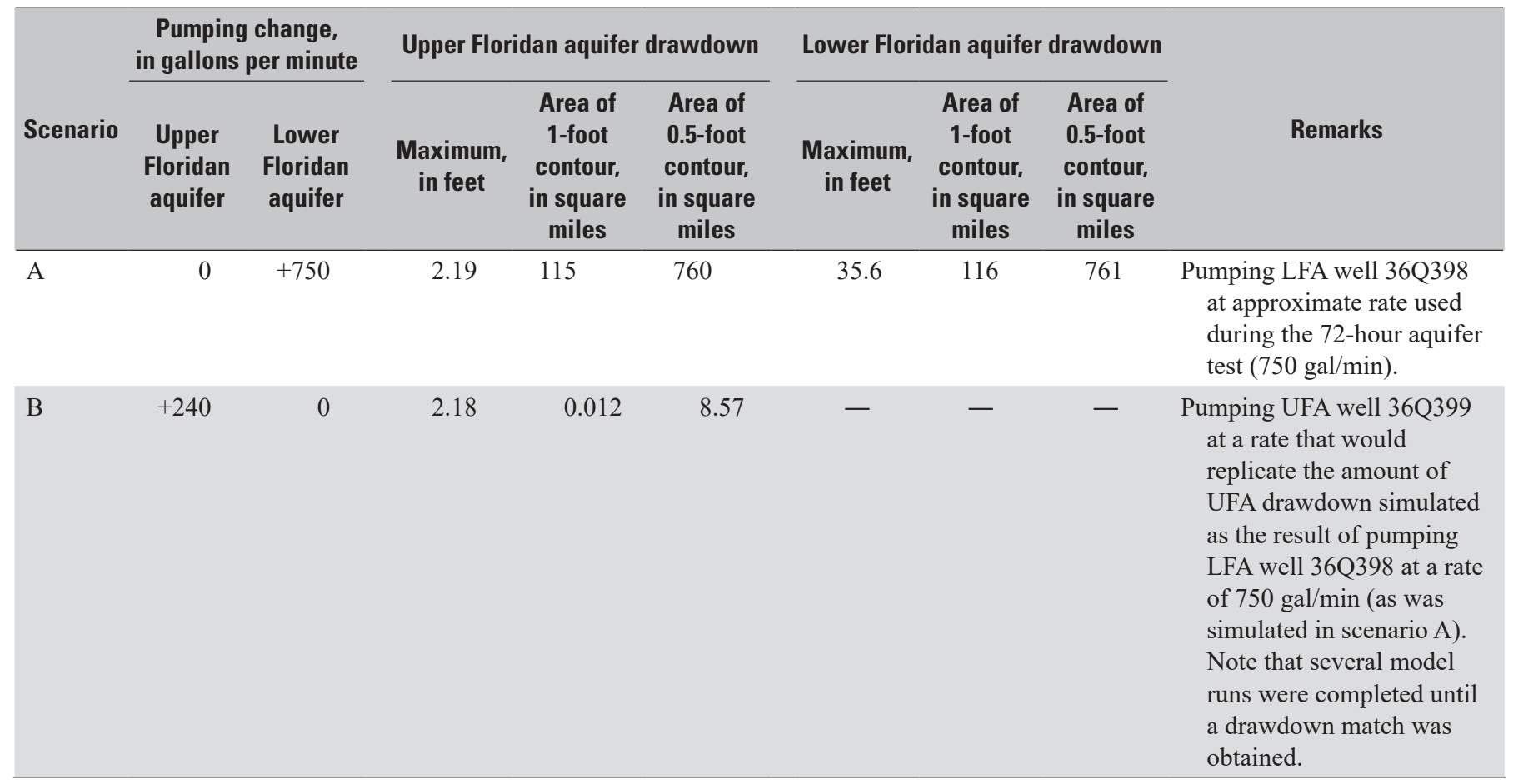

\section{Interaquifer Leakage and Drawdown Response}

For scenario A, simulated pumping of LFA well 36Q398 at a rate of $750 \mathrm{gal} / \mathrm{min}$ resulted in a maximum steady-state drawdown of $35.6 \mathrm{ft}$ (table 2, fig. 7), which is nearly identical to the 35.5 -ft maximum drawdown observed during the test (fig. 5). Because changes in water levels over time were approaching zero by the end of the 72-hour test, the steady-state simulation seems to be a reasonable estimate of field conditions in the LFA. Simulated steady-state drawdown in the LFA for scenario A exceeded $1 \mathrm{ft}$ over a 116- $\mathrm{mi}^{2}$ area (fig. 7, table 2).

Simulated pumping of LFA well $36 \mathrm{Q} 398$ at $750 \mathrm{gal} / \mathrm{min}$ (scenario A) caused interaquifer leakage through the LFCU, which resulted in drawdown in the overlying UFA (fig. 8). Because water levels in the UFA had not stabilized by the end of the 72-hour test, observed drawdown in well 36Q399 was considered a lower limit for steady-state model calibration. At the end of the 72-hour aquifer test, drawdown in well 36Q399 was $0.7 \mathrm{ft}$, compared to the simulated steady-state drawdown of $2.19 \mathrm{ft}$. This difference is expected because field data represent a short-term, transient condition in which drawdown in the UFA was still accumulating at the end of the 72-hour test, whereas the model simulated the long-term steady-state response. Model results for scenario A indicate that drawdown in the UFA exceeded $1 \mathrm{ft}$ over a $115-\mathrm{mi}^{2}$ area (table 2).

Simulated potentiometric surface for the UFA from scenario A resulted in no noticeable changes in the regional configuration of implied groundwater-flow directions for the UFA when compared with a base case representing year
2000 conditions (fig. 9). Groundwater flow in the region remained dominated by a large cone of depression centered over the Savannah, Ga., area.

To assess the amount of interaquifer leakage resulting from pumping in the LFA, the steady-state water budgets before and after pumping at well 36Q398 were compared (table 3). Because of independent rounding, the water budget values listed may not add to totals; however, comparison of values provides some insight into the relative contribution of flow to LFA well 36Q398. Pumping 1.08 Mgal/d (750 gal $/ \mathrm{min}$ ) at well 36Q398 resulted in small changes to the regional water budget and the following redistribution of flow among model layers (table 3):

- Layer 1 (surficial aquifer) - a 0.36-Mgal/d gain in inflow from, and a $0.08-\mathrm{Mgal} / \mathrm{d}$ reduction in outflow to, the general-head boundary for a net inflow of $0.44 \mathrm{Mgal} / \mathrm{d}$.

- Layer 2 (Brunswick aquifer confining unit) - a 0.018-Mgal $/ \mathrm{d}$ gain in inflow from, and a $0.002-\mathrm{Mgal} / \mathrm{d}$ reduction in outflow to, the general-head boundary for a net inflow of $0.020 \mathrm{Mgal} / \mathrm{d}$.

- Layer 5 (UFA) - a 0.01-Mgal/d gain in inflow from, and a $0.006-\mathrm{Mgal} / \mathrm{d}$ reduction in outflow to, the general-head boundary and a 0.38 -Mgal/d gain in inflow from, and $0.16-\mathrm{Mgal} / \mathrm{d}$ reduction in outflow to, lateral specified-head boundaries for a net inflow of $0.556 \mathrm{Mgal} / \mathrm{d}$. 
- Layer 7 (LFA) - a 0.014-Mgal/d gain in inflow from, and a $0.011-\mathrm{Mgal} / \mathrm{d}$ reduction in outflow to, lateral specified-head boundaries for a net inflow of $0.025 \mathrm{Mgal} / \mathrm{d}$.

For scenario A, of the 1.08-Mgal/d pumping rate in well 36Q398, an estimated 97.5 percent of the flow was derived from increased leakage from overlying layers, and 2.5 percent was from the lateral specified-head boundary for the LFA (layer 7). Most of the flow from overlying layers was from the general-head boundary in the surficial aquifer (layer 1, 41.6 percent) and lateral specified-head boundaries in the UFA (layer 5, 49.9 percent). The remainder of flow from overlying layers was contributed from the general-head boundary in layers 2 and 5.

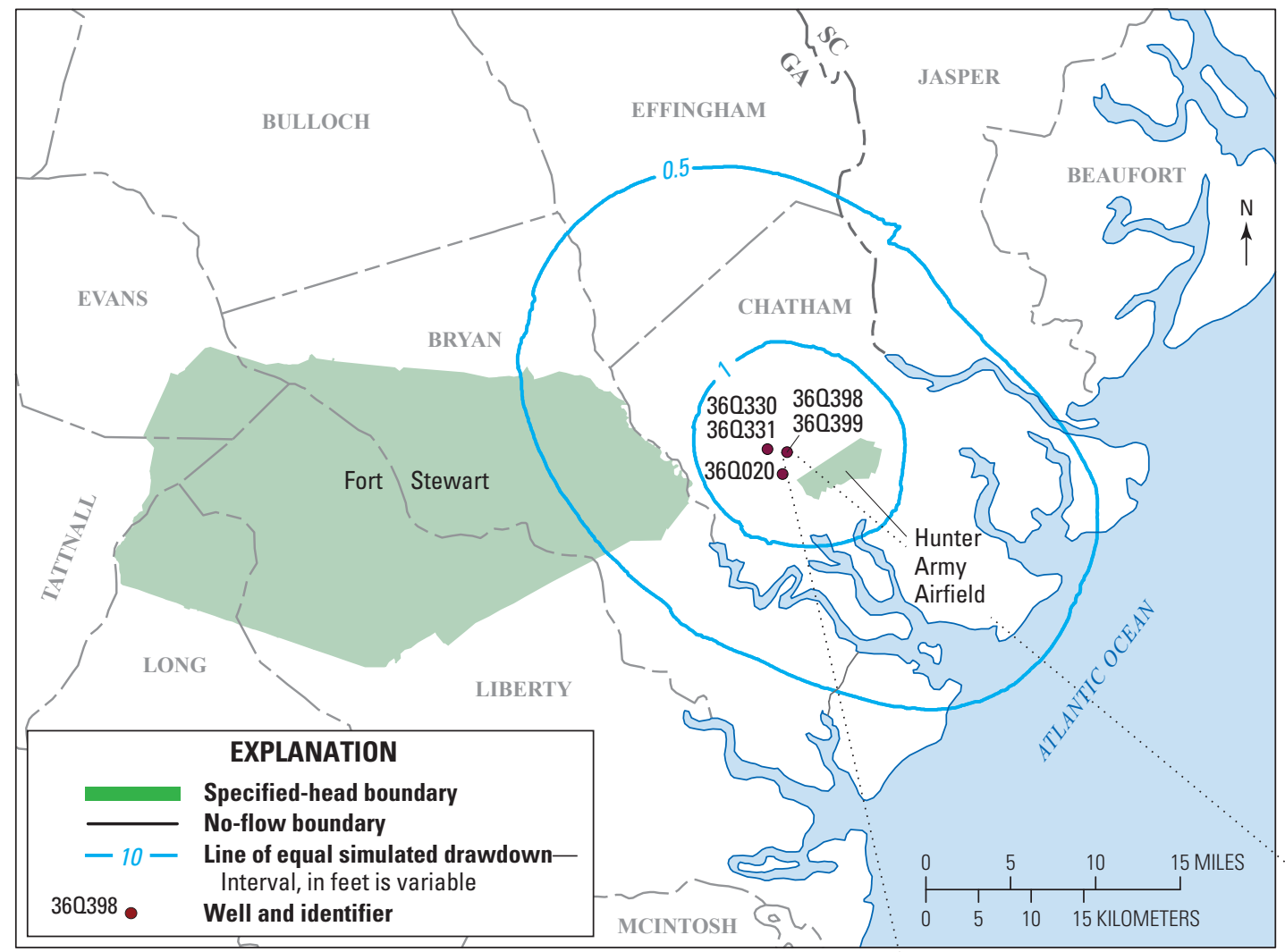

Base map from U.S. Geological Survey

1:2,000,000-scale digital data
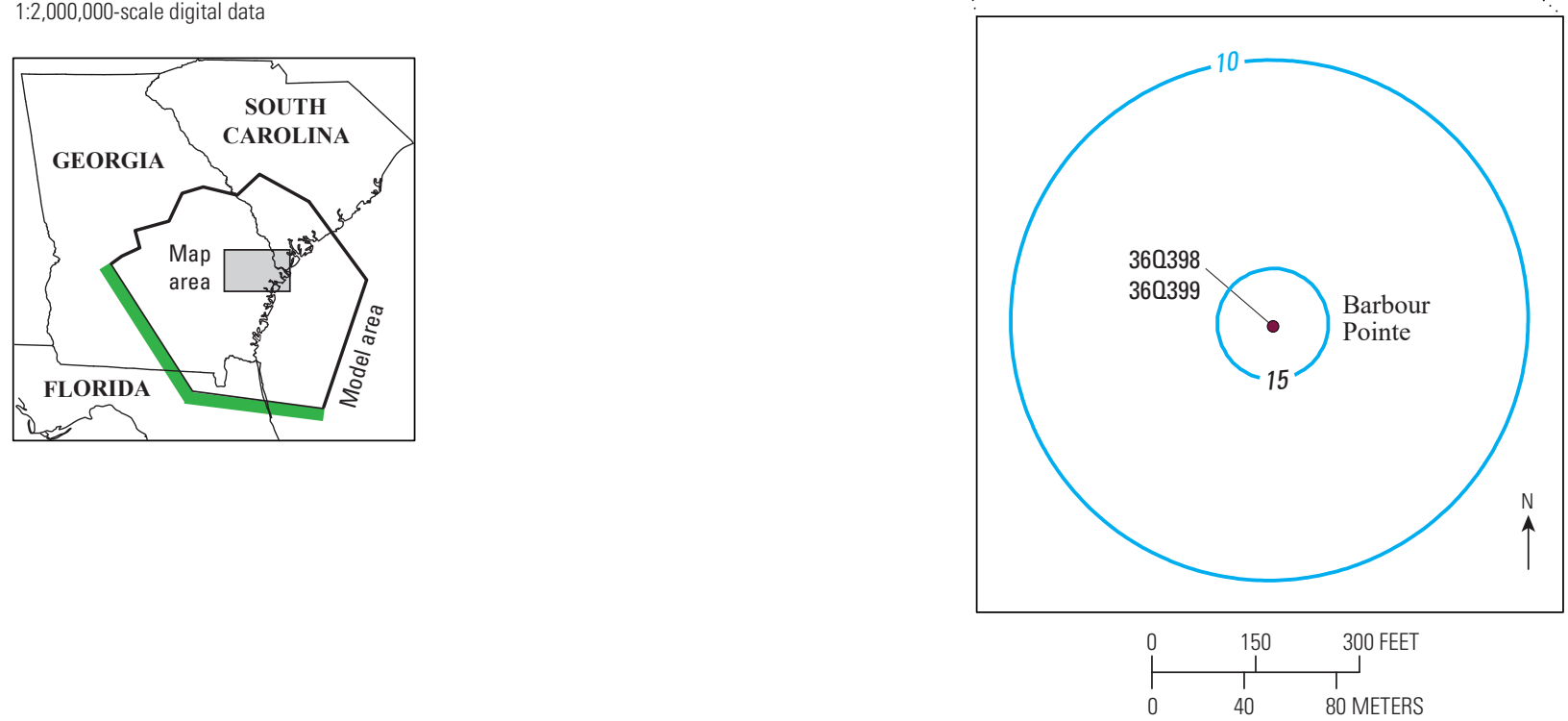

Figure 7. Simulated steady-state drawdown in the Lower Floridan aquifer for scenario A—pumping Lower Floridan aquifer well 360398 at 750 gallons per minute, Barbour Pointe, Georgia, and vicinity. Maximum drawdown in well 360398 is 35.6 feet. 


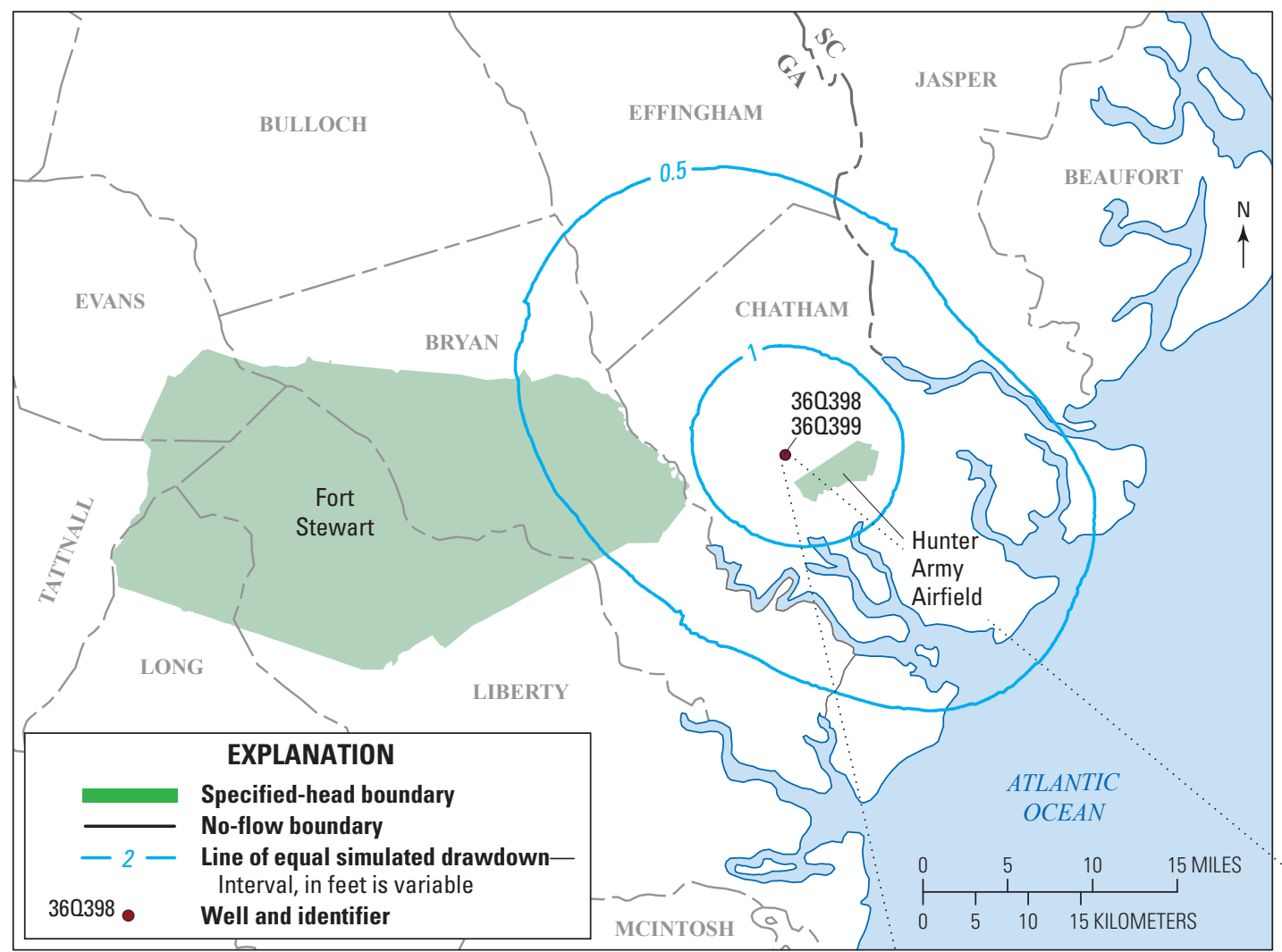

Base map from U.S. Geological Survey

1:2,000,000-scale digital data
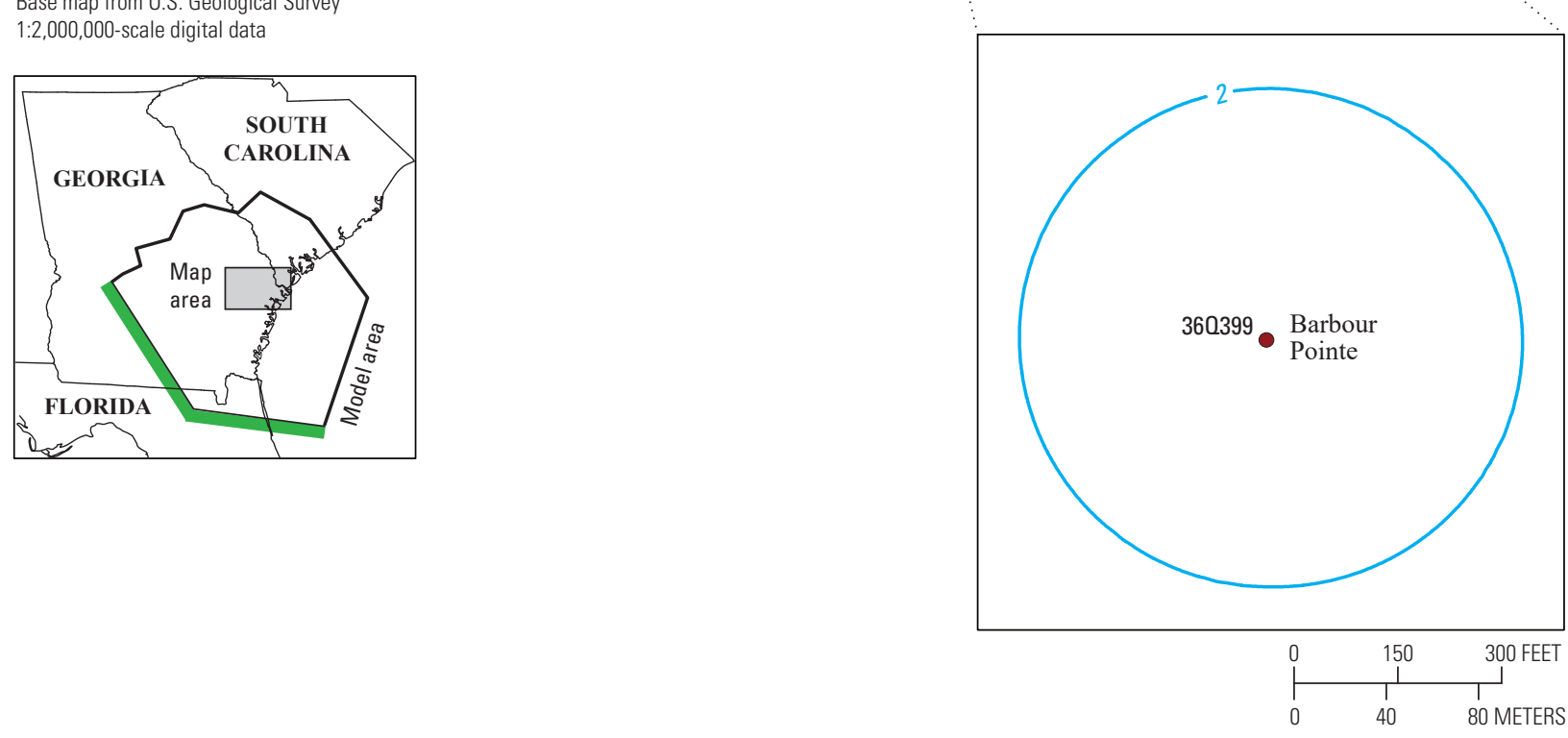

Figure 8. Simulated steady-state drawdown in the Upper Floridan aquifer for scenario A—pumping Lower Floridan aquifer well 360398 at 750 gallons per minute, Barbour Pointe, Georgia, and vicinity. Maximum drawdown in well 360399 is 2.19 feet. 


\section{Base Case}

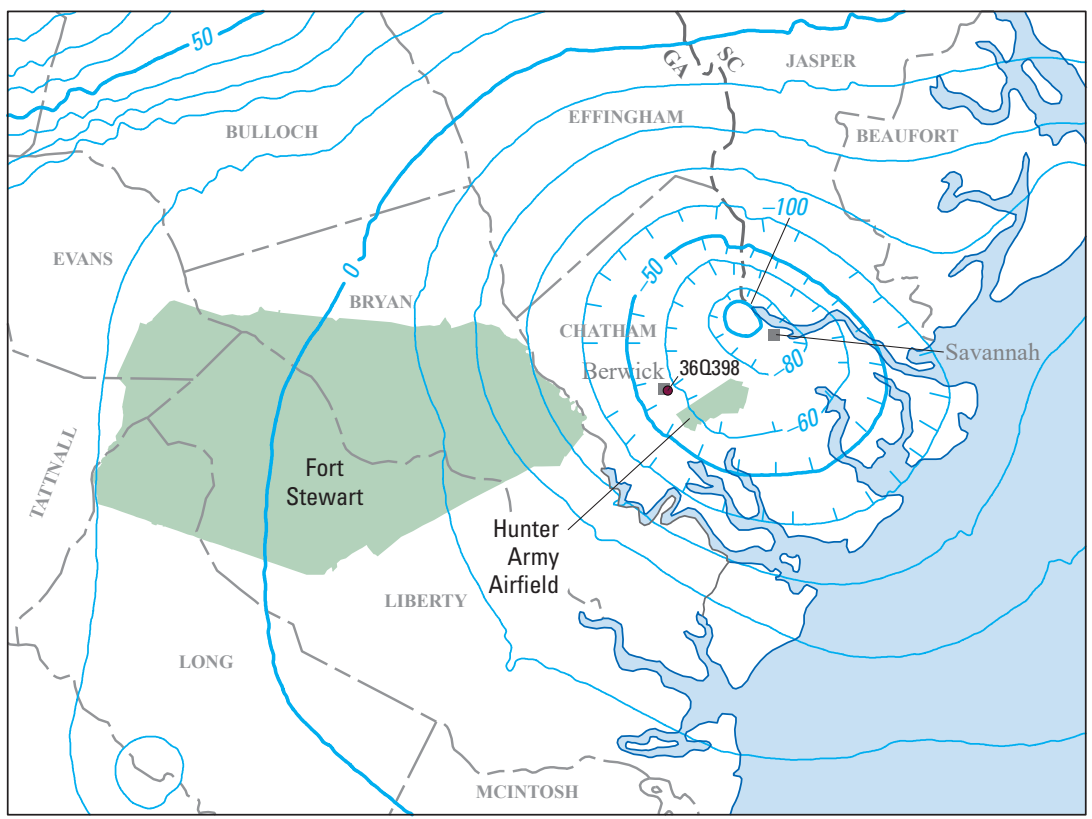

Scenario A

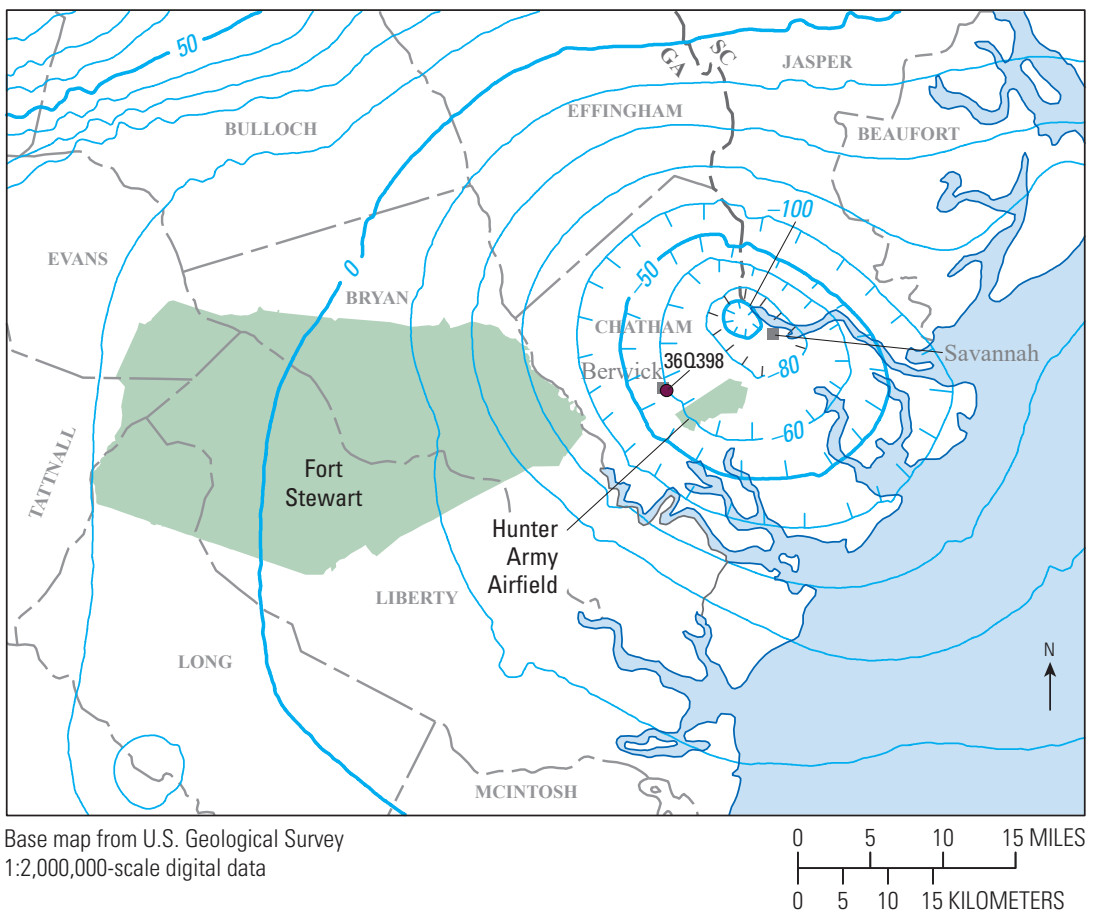

\section{EXPLANATION}

— 50 Simulated potentiometric contour-Intervals 10 and 20 feet.
Hachures indicate depression. Datum is NAVD 88
360398 Well and identifier

Figure 9. Simulated Upper Floridan aquifer potentiometric surface for the year 2000 base case and scenario A, Barbour Pointe, Georgia, and vicinity. 


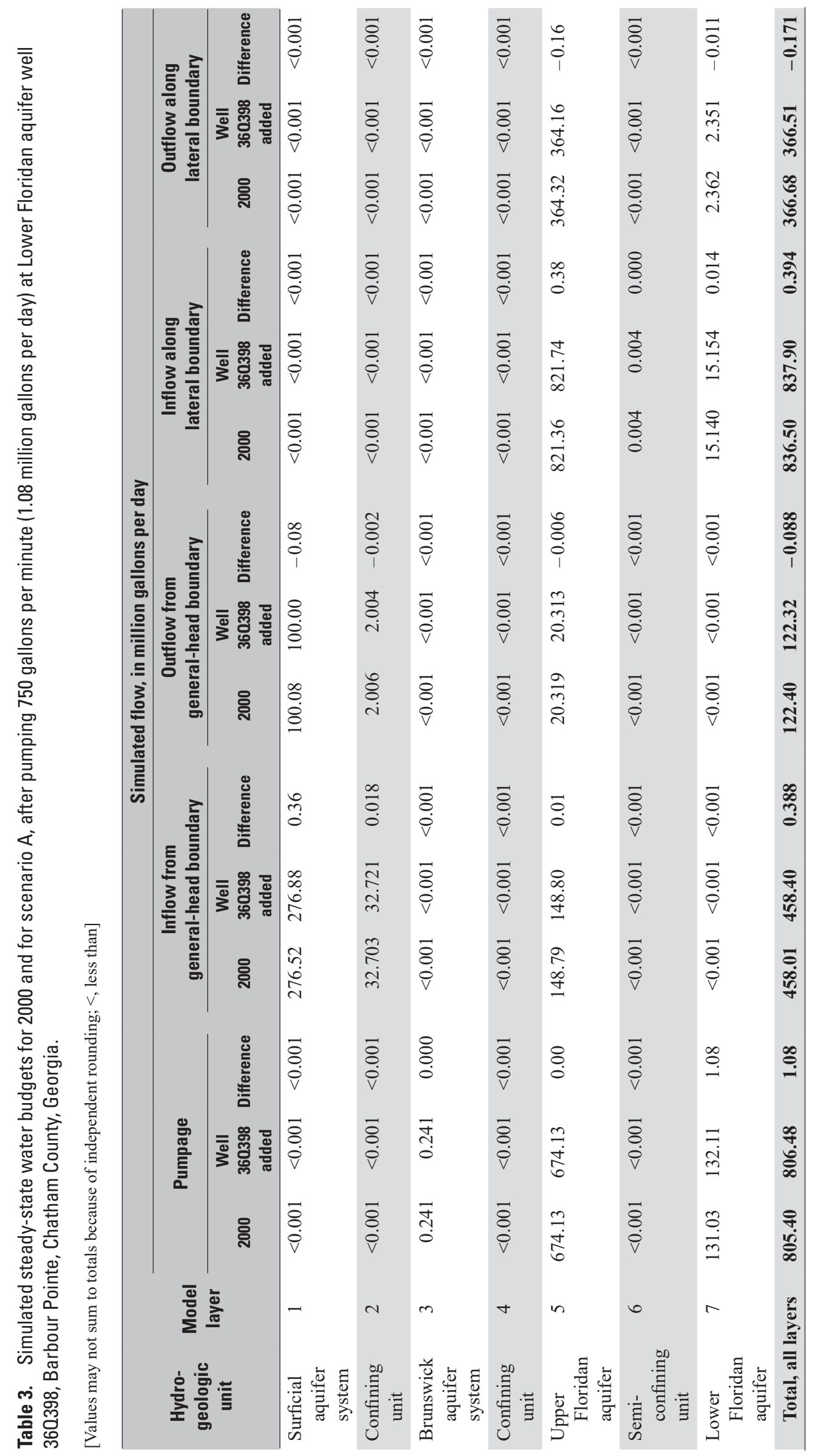




\section{Upper Floridan Aquifer Drawdown Offset}

As part of the interim permitting strategy for the LFA, GaEPD established a hydrogeologic-study protocol, which states that a groundwater model shall be used ". . . to simulate the equivalent Upper Floridan pumping that induces the identical maximum drawdown in the Upper Floridan that would be expected as a result of pumping the Lower Floridan." (Nolton Johnston, Georgia Environmental Protection Division, written commun., 2003). The amount of equivalent UFA pumping required to offset the effect of anticipated LFA pumping would be derived from pumping reductions at existing production wells within a 5-mile radius of the LFA well.

Scenario B was designed to determine the pumping rate in the UFA that would produce the identical maximum drawdown in the UFA as pumping from the LFA (herein called "drawdown offsets"). Scenario B is a series of steady-state simulations, applying various pumping rates to UFA well 36Q399, that were completed to match UFA drawdown as simulated by scenario A (table 2). Simulated pumping of UFA well 36Q399 at a rate of $240 \mathrm{gal} / \mathrm{min}$ approximated the 2.19 -ft maximum drawdown in the UFA resulting from pumping LFA well 36Q398 at $750 \mathrm{gal} / \mathrm{min}$ (scenario A, table 2). A map showing drawdown in the UFA resulting from scenario $B$ is not shown because of the small area affected by pumping.

Although it is possible to derive a drawdown offset for the UFA that produces the same maximum drawdown as that induced by leakage caused by pumping the LFA, that resultant UFA pumping will not produce the same overall drawdown pattern in the UFA as that produced by pumping the LFA. Pumping LFA well 36Q398 (scenario A; table 2) produced a larger drawdown area in the UFA than scenario $B$ in which UFA well 36Q399 was pumped to offset the maximum UFA drawdown. For example, the 1-ft drawdown contour in the UFA corresponding to scenario B (pumping the UFA) encompassed an area of $0.012 \mathrm{mi}^{2}$, whereas the 1 - $\mathrm{ft}$ contour encompassed $115 \mathrm{mi}^{2}$ in the UFA when the LFA was pumped (scenario A).

The large difference in affected area between scenarios involving pumping UFA and LFA wells is a consequence of the differences in hydraulic properties between the aquifers and the manner in which water flows to the simulated wells as leakage and from lateral boundaries. Drawdown in the UFA resulting from pumping the LFA has a more gradual lateral gradient and covers a wider area, whereas drawdown resulting from a well pumping directly from the UFA results in a steeper cone of depression covering a smaller area.

Pumping from the LFA produces a steep hydraulic gradient in that aquifer in the vicinity of the pumped well, progressively decreasing away from the well. Drawdown resulting from pumping LFA well 36Q398 extends to lateral specified-head boundaries in both the UFA and LFA, with boundaries in the UFA contributing relatively more flow than boundaries in the LFA for scenario A (table 2). The tenfold greater transmissivity of the UFA relative to the LFA enables drawdown to propagate over larger areas.

Comparison of water-budget values for components derived from simulating 2000 conditions without LFA pumpage with similar component values corresponding to drawdown-offset pumpage at UFA well 36Q399 (scenario B; table 4) indicated small changes to the 2000 regional water budget and the following redistribution of groundwater flow among model layers:

- Layer 1 (surficial aquifer) - a 0.12-Mgal/d gain in inflow from, and a $0.02-\mathrm{Mgal} / \mathrm{d}$ reduction in outflow to, the general-head boundary for a net inflow of $0.14 \mathrm{Mgal} / \mathrm{d}$.

- Layer 2 (Brunswick aquifer system confining unit)-a 0.006-Mgal/d gain in inflow from the general-head boundary.

- Layer 5 (UFA) - a 0.002-Mgal/d reduction in outflow to the general-head boundary and a $0.08-\mathrm{Mgal} / \mathrm{d}$ gain in flow from, and $0.05-\mathrm{Mgal} / \mathrm{d}$ reduction in outflow to, lateral specified-head boundaries for a net inflow of $0.132 \mathrm{Mgal} / \mathrm{d}$.

- Layer 7 (LFA) - a 0.004-Mgal/d in inflow from, and a $0.004-\mathrm{Mgal} / \mathrm{d}$ reduction in outflow to, lateral specified-head boundaries for a net inflow of $0.008 \mathrm{Mgal} / \mathrm{d}$.

For scenario B, 42 percent of the $0.346-\mathrm{Mgal} / \mathrm{d}$ pumping rate in well 36Q399 was derived from increased leakage from overlying layers, and 38 percent was derived from generaland specified-head boundaries for the UFA (layer 5; table 4). About 40 percent of the inflow to the pumped UFA well from overlying layers was derived from the general-head boundary in the surficial aquifer $(0.14 \mathrm{Mgal} / \mathrm{d}$; layer 1$)$; the remaining inflow to well 36Q399 from overlying layers was contributed by the general-head boundary in the Brunswick aquifer system confining unit (layer 2).

\section{Model Sensitivity}

To assess the relative importance of model parameters to groundwater levels and flow rates, Payne and others (2005) provided a comprehensive sensitivity analysis of the original regional model for both 1980 and 2000 simulations. Their evaluation included determination of composite-scaled sensitivities for pumping rate, horizontal and vertical hydraulic conductivity $\left(\mathrm{K}_{\mathrm{h}}\right.$ and $\mathrm{K}_{\mathrm{v}}$, respectively) for each hydraulicproperty zone, and the conductance of the general-head boundary using procedures described by Hill (1998). Results of this analysis indicate that the model is most sensitive, by a wide margin, to pumping variations, followed by $\mathrm{K}_{\mathrm{h}}$ of several zones in layer 5 (UFA). The $\mathrm{K}_{\mathrm{v}}$ of the LFCU (layer 6) was ranked near last ( 20 of 23 parameters). Additional model sensitivity analysis was performed using the modified regional model for the city of Pooler (Cherry and Clarke, 2013). The hydraulic-property zones established for the analysis at Pooler include Barbour Pointe and coincide with those used for the current modified regional model. According to Cherry and Clarke (2013), increases in $\mathrm{K}_{\mathrm{h}}$ and $\mathrm{K}_{\mathrm{v}}$ of the LFA in hydraulic-property zone LF2 (see appendix 1 for locations 


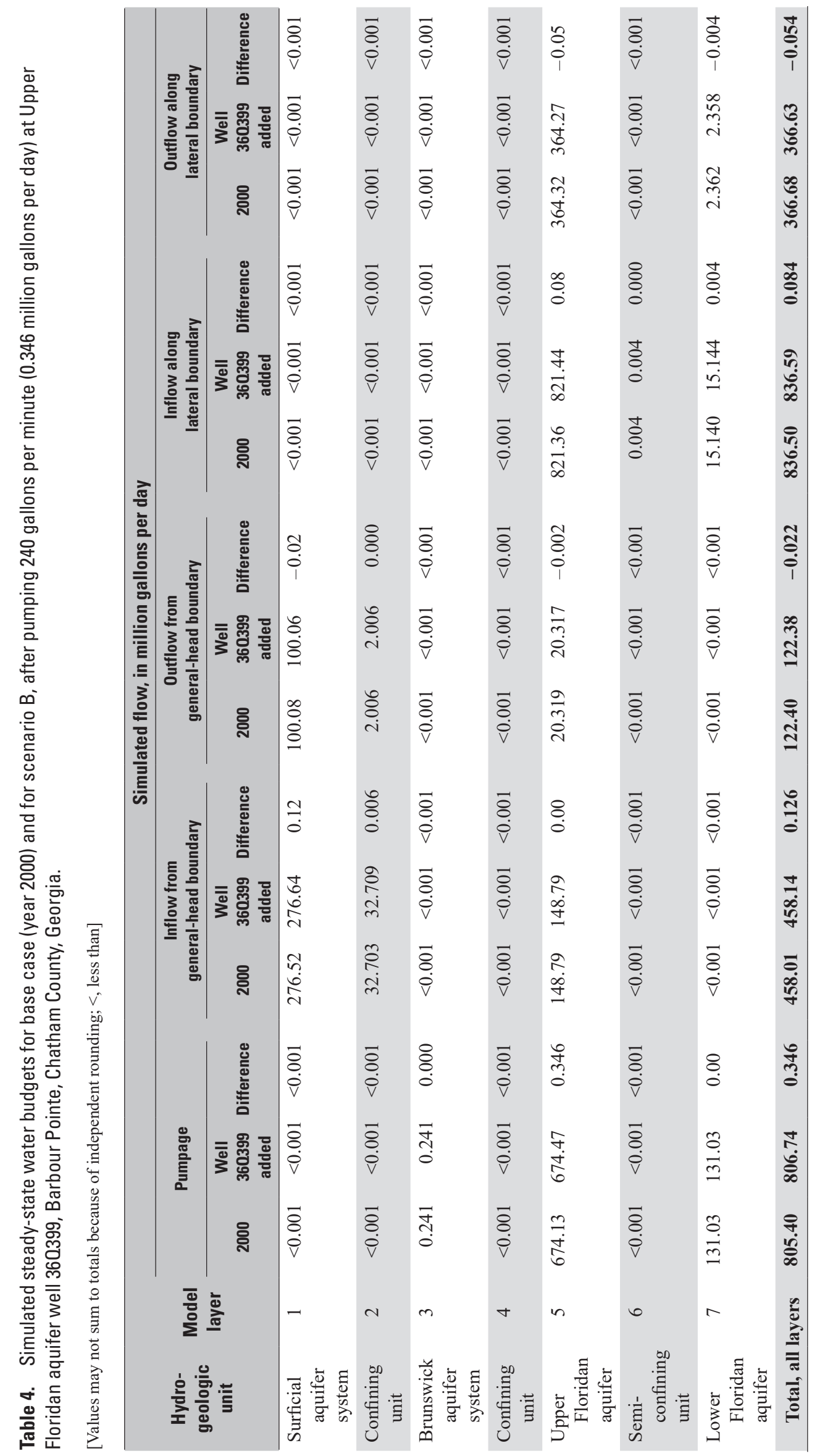


of hydraulic-property zones) resulted in lower drawdown in both the UFA and LFA, a slight decrease in flow from model general-head boundaries (recharge), and a slight increase in flow from lateral specified-head boundaries in the UFA and LFA. Increases in $\mathrm{K}_{\mathrm{h}}$ and $\mathrm{K}_{\mathrm{v}}$ of the UFA in zone F13 (see appendix 1) resulted in lower drawdown in both the UFA and LFA, decreased flow from the general-head boundaries, and increased flow from lateral specified-head boundaries in the UFA and LFA. Changing $\mathrm{K}_{\mathrm{h}}$ and $\mathrm{K}_{\mathrm{v}}$ of the LFA and UFA had virtually no effect on downward flow (leakage) from the LFCU to the LFA.

The same sensitivity analysis performed for the Pooler study indicated increases in $\mathrm{K}_{\mathrm{h}}$ and $\mathrm{K}_{\mathrm{v}}$ of the LFCU in zone LFC2 (see appendix 1) resulted in decreased maximum drawdown in the LFA and increased maximum drawdown in the UFA. The sensitivity analysis for the Barbour Pointe study focused on changes to $\mathrm{K}_{\mathrm{h}}$ and $\mathrm{K}_{\mathrm{v}}$ of the LFCU in zone LFC2 and the use of values considered to be the upper and lower endpoints in a range of values obtained from analysis of core samples at Hunter Army Airfield (Clarke and others, 2010). The nearly 10:1 ratio of horizontal to vertical hydraulic conductivity was also obtained from the core analysis and incorporated in the values used for the simulations. Hydraulic conductivity values of $\mathrm{K}_{\mathrm{h}}$ of $14.2 \mathrm{ft} / \mathrm{d}$ and $\mathrm{K}_{\mathrm{v}}$ of $1.67 \mathrm{ft} / \mathrm{d}$ were assigned as the higher endpoints based on the Rincon study where the 72-hour aquifer test indicated a strong interaquifer connection between the UFA and the LFA (Cherry and Clarke, 2015; table 1). Hydraulic conductivity values of $0.2 \mathrm{ft} / \mathrm{d}$ for $\mathrm{K}_{\mathrm{h}}$ and $0.02 \mathrm{ft} / \mathrm{d}$ for $\mathrm{K}_{\mathrm{v}}$ were assigned as the lower endpoints because of a more delayed response in the UFA to pumping in the LFA at Hunter Army Airfield (Clarke and others, 2010). Hydraulic conductivity values of $2 \mathrm{ft} / \mathrm{d}$ for $\mathrm{K}_{\mathrm{h}}$ and $0.2 \mathrm{ft} / \mathrm{d}$ for $\mathrm{K}_{\mathrm{v}}$ were assigned for the Pooler study and the current analysis for Barbour Pointe because the vertical hydraulic conductivity approximates the median value from the core analysis at Hunter Army Airfield (Cherry and Clarke, 2013; Clarke and others 2010). These changes in the hydraulic conductivity values assigned to the LFCU in zone LFC2 also required adjustments to hydraulic properties of the LFA in zone LF2 in order for simulated drawdown to match the observed drawdown in LFA pumping well 36Q398 after 72 hours.

Zone LF2 in layer 7 was expanded northwestward from an area of $114 \mathrm{mi}^{2}$ in the Hunter Army Airfield model to $221 \mathrm{mi}^{2}$ in the Pooler and Barbour Pointe models. Zone LF2 in layer 7 covers an area identical to zones F13 in layer 5 and LFC2 in layer 6, with a calibrated $\mathrm{K}_{\mathrm{h}}$ value of $114 \mathrm{ft} / \mathrm{d}$, compared to $88 \mathrm{ft} / \mathrm{d}$ for the calibrated Pooler model (Cherry and Clarke, 2013). Multiplying the $\mathrm{K}_{\mathrm{h}}$ value by the simulated thickness of the aquifer yields an estimated transmissivity of $5,647 \mathrm{ft}^{2} / \mathrm{d}$, which is slightly greater than the $5,100-\mathrm{ft}^{2} / \mathrm{d}$ value derived from field testing at Barbour Pointe (Gonthier and Clarke, 2016). Using higher hydraulic conductivities for $\mathrm{LFC} 2$ in layer $6\left(\mathrm{~K}_{\mathrm{h}}=14.2 \mathrm{ft} / \mathrm{d}, \mathrm{K}_{\mathrm{v}}=1.67 \mathrm{ft} / \mathrm{d}\right)$ resulted in a calibrated $\mathrm{K}_{\mathrm{h}}$ of $102 \mathrm{ft} / \mathrm{d}$ in zone LF2 in layer 7 that, when multiplied by the simulated thickness of the aquifer, yields an estimated transmissivity of $5,052 \mathrm{ft}^{2} / \mathrm{d}$. Using lower hydraulic conductivities for LFC2 in layer $6\left(\mathrm{~K}_{\mathrm{h}}=0.2 \mathrm{ft} / \mathrm{d}\right.$, $\mathrm{K}_{\mathrm{v}}=0.02 \mathrm{ft} / \mathrm{d}$ ) resulted in a calibrated $\mathrm{K}_{\mathrm{h}}$ of $123 \mathrm{ft} / \mathrm{d}$ in zone LF2 in layer 7 that, when multiplied by the simulated thickness of the aquifer, gives an estimated transmissivity of $6,093 \mathrm{ft}^{2} / \mathrm{d}$.

The changes to the hydraulic conductivities of LFC2 in layer 6 required recalibration of the horizontal hydraulic conductivity of zone LF2 in layer 7 and altered the maximum drawdown in the UFA directly above the LFA pumping well 36Q398. This, in turn, changes the determination of the pumping rate in the UFA that would produce an identical maximum drawdown in the UFA as pumping from the LFA (scenario B). Scenario B is a series of steady-state simulations, each applying a given pumping rate to UFA well 36Q399, that were completed to match UFA drawdown as simulated by scenario A (table 2). Simulated pumping of UFA well 36Q399 at a rate of $240 \mathrm{gal} / \mathrm{min}$ approximated the $2.19-\mathrm{ft}$ maximum drawdown in the UFA resulting from pumping LFA well 36Q398 at $750 \mathrm{gal} / \mathrm{min}$ (scenario A, table 2). Using higher hydraulic conductivities for LFC2 in layer $6\left(\mathrm{~K}_{\mathrm{h}}=14.2 \mathrm{ft} / \mathrm{d}\right.$, $\mathrm{K}_{\mathrm{v}}=1.67 \mathrm{ft} / \mathrm{d}$ ) resulted in a maximum drawdown in the UFA of $2.57 \mathrm{ft}$, which required simulated pumping of UFA well 36Q399 at a rate of $278 \mathrm{gal} / \mathrm{min}$ to produce identical drawdown. Using lower hydraulic conductivities for LFC2 in layer $6\left(\mathrm{~K}_{\mathrm{h}}=0.2 \mathrm{ft} / \mathrm{d}, \mathrm{K}_{\mathrm{v}}=0.02 \mathrm{ft} / \mathrm{d}\right)$ resulted in a maximum drawdown in the UFA of $1.82 \mathrm{ft}$, which required simulated pumping of UFA well 36Q399 at a rate of $199 \mathrm{gal} / \mathrm{min}$ to produce identical drawdown. This sensitivity analysis indicates the simulated offset pumping in the UFA ranges from 199 to $278 \mathrm{gal} / \mathrm{min}$, which represents 26.5 to 37 percent of the $750 \mathrm{gal} / \mathrm{min}$ pumping rate in LFA well 36Q398.

Additional model validation is provided by results from a transient simulation, which can be compared to the observed drawdown of $0.71 \mathrm{ft}$ at UFA well 36Q399 at the completion of the 72-hour aquifer test. The calibrated simulation of scenario A provided the best match, with a simulated drawdown after 72 hours of $0.87 \mathrm{ft}$ at UFA well 36Q399. Using higher hydraulic conductivities for LFC2 in layer 6 simulated a quicker response, with a simulated drawdown after 72 hours of $1.28 \mathrm{ft}$ at UFA well 36Q399. Using lower hydraulic conductivities for LFC2 in layer 6 simulated a delayed response, with a simulated drawdown after 72 hours of $0.46 \mathrm{ft}$ at UFA well 36Q399.

\section{Limitations of Analysis}

Analysis of the effects of pumping the LFA on water levels in the UFA is limited by the accuracy of field data, including possible errors and uncertainty in water-level measurements, hydraulic properties, and pumping (not quantified in this report). Although water-level data were filtered to minimize or eliminate the effects of local interferences, such as tides, barometric pressure, and pumping (Gonthier and Clarke, 2016), some interferences could remain and affect recorded levels to some degree and, thus, affect computed hydraulic properties. 
The revised model of Payne and others (2005) reasonably depicts changes in groundwater levels resulting from pumping the LFA at Barbour Pointe at a rate of $750 \mathrm{gal} / \mathrm{min}$. Results are limited by the same model assumptions and design as described by Payne and others (2005). These limitations include inaccuracies in the conceptual model of groundwater flow; approximations made in representing the physical properties of the flow system and errors inherent in estimating the spatial distribution of these properties; approximations made in the formulation and application of model boundary and initial conditions; errors associated with numerical approximation and solution of the mathematical model of the flow system; and assumptions made in using the models to predict the future behavior of the flow system, such as no variations in recharge rates or boundary heads.

The variably spaced grid used in the revised model contains aspect ratios between row and column dimensions as large as 1,013:1, which can lead to numerical errors (de Marsily, 1986, p. 351). Fortunately, these large aspect ratio grid cells are only in areas distant from Barbour Pointe and have little effect on simulated results in the area (see calibration results in appendix 1).

Sensitivity analysis was completed for a model constructed to simulate flow in the FAS at the nearby city of Pooler (Cherry and Clarke, 2013). Because the Pooler model has similar model layering, boundary conditions, hydraulic properties, and hydrologic conditions as the Barbour Pointe model, results of sensitivity analysis are probably similar to what would be expected at Barbour Pointe. Simulation results at Pooler indicated that drawdown in the UFA and LFA is most sensitive to variations in $\mathrm{K}_{\mathrm{h}}$ and $\mathrm{K}_{\mathrm{v}}$ of the UFA and LFA in hydraulic-property zones F13 and LF2, respectively (Cherry and Clarke, 2013). Errors in computation of these values would affect simulated maximum drawdown and associated drawdown offset computations.

Simulated rates of interaquifer leakage and drawdown in the UFA can differ from actual rates because of the influence of specified-head and general-head boundaries, which allow an unlimited amount of water exchange between the model and the aquifer region that extends beyond the model grid. This unlimited supply can affect simulated drawdown and rates of interaquifer leakage. Lastly, although the revised groundwater flow model reasonably simulates steady-state conditions, additional analysis using a transient simulation would provide insight into drawdown and groundwater leakage over time.

\section{Summary}

Model simulation was used to assess the potential effects on the Upper Floridan aquifer (UFA) of pumping at a new well, completed in the Lower Floridan aquifer (LFA) and located at Barbour Pointe, in western Chatham County, Georgia. An existing regional groundwater-flow model that simulated steady-state flow in the Floridan aquifer system
(FAS) was modified with a fine spatial resolution and detailed hydrogeologic information resulting from field investigations at Barbour Pointe and existing wells in the area. Model scenarios were completed whereby

- the LFA was pumped at a rate of 750 gallons per minute (gal/min), the approximate rate of a 72 -hour aquifer test (scenario $\mathrm{A}$ ); and

- the UFA was pumped at a rate of $240 \mathrm{gal} / \mathrm{min}$ (scenario B), the amount of pumping required to produce an identical drawdown response in the UFA as scenario A (drawdown offset).

The major findings are summarized as follows:

- Long-term pumping at a rate of $750 \mathrm{gal} / \mathrm{min}$ from the LFA would cause a simulated maximum drawdown of about 2.19 feet in the UFA, with drawdown exceeding 1 foot over a 115-square-mile area. This pumping resulted in no discernible change in the configuration of the simulated UFA potentiometric surface.

- Induced vertical interaquifer leakage from the UFA provided about 98 percent of the water to the LFA, with the remainder from lateral specifiedhead boundaries in the LFA. The effects of this interaquifer leakage on the UFA, although slight with regard to drawdown in the UFA, extend into the Coastal Plain beyond Barbour Pointe because of the relatively large (about 10:1) contrast in the water-transmitting ability, or transmissivity, of the UFA compared with that of the LFA.

- Simulated pumping changed regional water-budget components slightly and redistributed flow among model layers; namely increasing inflow to, and decreasing outflow from, lateral specified-head boundaries in the UFA and LFA, and increasing inflow (recharge) from the general-head boundary to outcrop areas in model layers 1, 2, and 5 (surficial aquifer system, Brunswick aquifer system confining unit, and UFA, respectively).

- Simulations run to address the interaquifer leakage or drawdown offset of the Georgia Environmental Protection Division (GaEPD) interim permitting strategy identified widely varying pumping offsets for the UFA, depending on whether the interaquifer leakage or the drawdown offset for UFA pumping was evaluated. When pumping the LFA for scenario $\mathrm{A}$, interaquifer leakage from overlying layers accounted for about 98 percent of flow to the well. When pumping the UFA to replicate the simulated maximum drawdown resulting from pumping the LFA (scenario B, drawdown offset), leakage accounted for 32 percent of the LFA pumping rate. 
- Simulated rates of interaquifer leakage and drawdown offset in the UFA can differ from actual rates because of the influence of specified- and general-head boundaries, which supply an unlimited amount of water to the groundwater system. This unlimited supply may result in differences in simulated drawdown offset and rates of interaquifer leakage. Simulation results could be improved by replacing lateral specified-head boundaries with a natural boundary, such as a groundwater divide, and by using active simulation of the surficial aquifer. Simulation results have improved regional characterization of the FAS, which may be used by State officials in evaluating requests for groundwater withdrawals from the LFA.

\section{References Cited}

Carter and Sloope, 2004, Hydrogeologic characterization Lower Floridan aquifer, Effingham County, Georgia: Savannah, Ga., Carter and Sloope Consulting Engineers, Report for City of Rincon.

Cherry, G.S., 2017, MODFLOW grid for simulations used to evaluate the potential effect of Lower Floridan aquifer groundwater pumping on the Upper Floridan aquifer at Barbour Pointe community in Chatham County, Georgia: U.S. Geological Survey data release, accessed September 2017 at http://dx.doi.org/10.5066/F7VH5KZ1.

Cherry G.S., and Clarke, J.S., 2013, Simulated effects of Lower Floridan aquifer at Pooler, Chatham County, Georgia: U.S. Geological Survey Scientific Investigations Report 2013-5004, 46 p., accessed May 4, 2015, at http://pubs.usgs.gov/sir/2013/5004/.

Cherry, G.S., and Clarke, J.S., 2015, Simulated effects of Lower Floridan aquifer pumping on the Upper Floridan aquifer at Rincon, Effingham County, Georgia: U.S. Geological Survey Scientific Investigations Report 2015-5072, 35 p., accessed September 2015 at http://dx.doi.org/10.3133/sir20155072.

Clarke, J.S., 2003, The surficial and Brunswick aquifer systems-Alternative ground-water resources for coastal Georgia, in Hatcher, K.J., ed., Proceedings of the 2003 Georgia Water Resources Conference, April 23-24, 2003, The University of Georgia, Institute of Ecology, Athens, Ga., CD-ROM.

Clarke, J.S., Cherry, G.C., and Gonthier, G.J., 2011, Hydrogeology and water quality of the Floridan aquifer system and effects of Lower Floridan aquifer pumping on the Upper Floridan aquifer at Fort Stewart, Georgia: U.S. Geological Survey Scientific Investigations Report 2011-5065, 59 p., accessed May 4, 2015, at http://pubs.usgs.gov/sir/2011/5065/.

Clarke, J.S., Hacke, C.M., and Peck, M.F., 1990, Geology and ground-water resources of the coastal area of Georgia: Georgia Geologic Survey Bulletin 113, 106 p.
Clarke, J.S., and Krause, R.E., 2000, Design, revision, and application of ground-water flow models for simulation of selected water-management scenarios in the coastal area of Georgia and adjacent parts of South Carolina and Florida: U.S. Geological Survey Water-Resources Investigations Report 00-4084, 93 p.

Clarke, J.S., Williams, L.J., and Cherry, G.C., 2010, Hydrogeology and water quality of the Floridan aquifer system and effect of Lower Floridan aquifer pumping on the Upper Floridan aquifer at Hunter Army Airfield, Chatham County, Georgia: U.S. Geological Survey Scientific Investigations Report 2010-5080, 56 p., accessed May 4, 2015, at http://pubs.usgs.gov/sir/2010/5080/.

de Marsily, Ghislain, 1986, Quantitative hydrogeology: Orlando, Florida, Academic Press, Inc., 440 p.

Falls, W.F., Baum, J.S., Harrelson, L.G., Brown, L.H., and Jerden, J.L., Jr., 1997, Geology and hydrogeology of Cretaceous and Tertiary strata, and confinement in the vicinity of the U.S. Department of Energy Savannah River Site, South Carolina: U.S. Geological Survey Water-Resources Investigations Report 97-4245, 125 p.

Fanning, J.L., and Trent, V.P., 2009, Water use in Georgia by county for 2005; and water-use trends, 1980-2005: U.S. Geological Survey Scientific Investigations Report 2009-5002, 186 p., accessed May 4, 2015, at http://pubs.usgs.gov/sir/2009/5002/.

Faye, R.E., and Gill, H.E., 2005, Computation of leakance of the middle semiconfining unit, Floridan aquifer system, Berwick Plantation, Chatham County, Georgia, in Hatcher, K.J., ed., Proceedings of the 2005 Georgia Water Resources Conference, April 25-27, 2005: Athens, Georgia, The University of Georgia Water Resources Institute, 4 p. [Also available at http://www.gwri.gatech.edu/sites/default/files/ files/docs/2005/FayeR-GWRCpaper.pdf.]

Georgia Department of Natural Resources, 2006, Coastal Georgia Water \& Wastewater Permitting Plan for Managing Salt Water Intrusion: Accessed September 7, 2012, at http://www1.gadnr.org/cws/Documents/saltwater_ management_plan_june2006.pdf.

Georgia Department of Natural Resources, 2013, Closure of red and yellow zones of Floridan aquifer to new withdrawals: Environmental Protection Division Web site, accessed June 12, 2013, at http://epd.dnr.state.ga.us/Files_PDF/whats_news/ ClosureofRedandYellowZonesofFloridanAquifertoNewWithdrawals.pdf.

Gonthier, G.J., 2011, Summary of hydrologic testing of the Floridan aquifer system at Fort Stewart, Georgia: U.S. Geological Survey Open-File Report 2011-1020, 40 p., accessed May 4, 2015, at http://pubs.usgs.gov/of/2011/1020/. 
Gonthier, G.J., 2012, Hydrogeology and water quality of the Floridan aquifer system and effect of Lower Floridan aquifer pumping on the Upper Floridan aquifer, Pooler, Chatham County, Georgia, 2011-2012: U.S. Geological Survey Scientific Investigations Report 2012-5249, 62 p., accessed May 4, 2015, at http://pubs.usgs.gov/sir/2012/5249/.

Gonthier, G.J., and Clarke, J.S., 2016, Hydrogeology and water quality of the Floridan aquifer system and effect of Lower Floridan aquifer withdrawals on the Upper Floridan aquifer at Barbour Pointe Community, Chatham County, Georgia, 2013: U.S. Geological Survey Scientific Investigations Report 2016-5028, 56 p., accessed March 2016 at http://dx.doi.org/10.3133/sir20165028.

Halford, K.J., 2006, Documentation of a spreadsheet for time-series analysis and drawdown estimation: U.S. Geological Survey Scientific Investigations Report 2006-5024, 38 p.

Harbaugh, A.W., 1990, A computer program for calculating subregional water budgets using results from the U.S. Geological Survey modular three-dimensional finitedifference ground-water flow model: U.S. Geological Survey Open-File Report 90-392, 46 p.

Harbaugh, A.W., Banta, E.R., Hill, M.C., and McDonald, M.G., 2000, MODFLOW-2000, The U.S. Geological Survey modular ground-water model - User guide to modularization concepts and the ground-water flow process: U.S. Geological Survey Open-File Report 00-92, 121 p., accessed May 5, 2015, at http://water.usgs.gov/nrp/ gwsoftware/modflow2000/ofr00-92.pdf.

Hill, M.C., 1998, Methods and guidelines for effective model calibration: U.S. Geological Survey Water-Resources Investigation Report 98-4005, 90 p.

Jordan, Jones, and Goulding, Inc., 2002, Lower Floridan aquifer production well, Berwick Plantation, Chatham County, Georgia-Hydrogeologic characterization: Norcross, Ga., Jordan, Jones, and Goulding, Inc.

Krause, R.E., and Clarke, J.S., 2001, Coastal ground water at risk-Saltwater contamination at Brunswick, Georgia, and Hilton Head Island, South Carolina: U.S. Geological Survey Water-Resources Investigations Report 01-4107, 1 sheet.

Krause, R.E., and Randolph, R.B., 1989, Hydrology of the Floridan aquifer system in southeast Georgia and adjacent parts of Florida and South Carolina: U.S. Geological Survey Professional Paper 1403-D, 65 p., 18 pl.

Miller, J.A., 1986, Hydrogeologic framework of the Floridan aquifer system in Florida and in parts of Georgia, Alabama, and South Carolina: U.S. Geological Survey Professional Paper 1403-B, 91 p., 33 pl.
Payne, D.F., Abu Rumman, Malek, and Clarke, J.S., 2005, Simulation of ground-water flow in coastal Georgia and adjacent parts of South Carolina and Florida - Predevelopment, 1980, and 2000: U.S. Geological Survey Scientific Investigations Report 2005-5089, 91 p., accessed May 4, 2015, at http://pubs.usgs.gov/sir/2005/5089/.

Peaceman, D.W., 1983, Interpretation of well-block pressures in numerical reservoir simulation with nonsquare grid blocks and anisotropic permeability: Society of Petroleum Engineers Journal, v. 23, no. 3, p. 531-543.

Peck, M.F., Clarke, J.S., Ransom, Camille, III, and Richards, C.J., 1999, Potentiometric surface of the Upper Floridan aquifer in Georgia and adjacent parts of Alabama, Florida, and South Carolina, May 1998, and water level-trends in Georgia, 1990-98: Georgia Geologic Survey Hydrologic Atlas 22, 1 sheet, scale 1:100,000, 1977-81.

Priest, Sherlyn, 2004, Stream-aquifer relations in the coastal area of Georgia and adjacent parts of Florida and South Carolina: Georgia Geologic Information Circular 108, $40 \mathrm{p}$.

Randolph, R.B., Pernik, Maribeth, and Garza, Reggina, 1991, Water-supply potential of the Floridan aquifer system in the coastal area of Georgia-A digital model approach: Atlanta, Georgia Geologic Survey Bulletin 116, 30 p.

Southeast Regional Climate Center, 2011, Savannah WSO Airport, Georgia — Climate summary: Accessed September 27, 2011, at http://www.sercc.com/cgi-bin/sercc/ cliMAIN.pl?ga7847.

Weems, R.E., and Edwards, L.E., 2001, Geology of Oligocene, Miocene, and younger deposits in the coastal area of Georgia: Atlanta, Georgia Geologic Survey Bulletin 131, 124 p.

Williams, L.J., 2010, Summary of hydrologic testing of the Floridan aquifer system at Hunter Army Airfield, Chatham County, Georgia: U.S. Geological Survey Open-File Report 2010-1066, 30 p., accessed May 4, 2015, at http://pubs.usgs.gov/of/2010/1066/.

Williams, L.J., and Gill, H.E., 2010, Revised hydrogeologic framework of the Floridan aquifer system in the northern coastal area of Georgia and adjacent parts of South Carolina: U.S. Geological Survey Scientific Investigations Report 2010-5158, 103 p., 3 pl., accessed May 4, 2015, at http://pubs.usgs.gov/sir/2010/5158/.

Williams, L.J., and Kuniansky, E.L., 2015, Revised hydrogeologic framework of the Floridan aquifer system in Florida and parts of Georgia, Alabama, and South Carolina: U.S. Geological Survey Professional Paper 1807, 140 p., 23 pl., accessed September 9, 2015, at http://pubs.usgs.gov/pp/1807/. 


\section{Appendix 1. Regional Groundwater Model}

A regional groundwater flow model (herein referred to as "regional model") developed by Payne and others (2005) for the coastal region of Georgia and adjacent parts of South Carolina and Florida was modified and used to simulate the effects of pumping from the Lower Floridan aquifer at Barbour Pointe, in Chatham County, Georgia. The regional model is described in detail in Payne and others (2005); a brief description of the model follows.

The regional model uses MODFLOW-2000 (Harbaugh and others, 2000) to simulate flow in the surficial, Brunswick, and Floridan aquifer systems. To account for natural hydrologic boundaries, the model encompasses a 42,155-squaremile $\left(\mathrm{mi}^{2}\right)$ area that includes the Coastal Plain of Georgia, northeastern Florida, southwestern South Carolina, and the adjacent offshore area (see fig. 1-1). All data input files and corresponding output are provided in Cherry (2017).

The regional model consists of the following seven model layers and corresponding hydrogeologic units (fig. 1-2) in descending order:

- Layer 1: Confined upper and lower water-bearing zones of the surficial aquifer system.

- Layer 2: Brunswick aquifer system confining unit.

- Layer 3: Upper and lower Brunswick aquifers, composing the Brunswick aquifer system.

- Layer 4: Upper Floridan aquifer confining unit.

- Layer 5: Upper Floridan aquifer (UFA).

- Layer 6: Lower Floridan semiconfining unit (LFCU).

- Layer 7: Lower Floridan aquifer (LFA).

These units crop out to the northwest of the study area and generally dip and thicken to the southeast. The thickness, extent, and other hydraulic properties of these units, as well as the model development process, are described in detail in Payne and others (2005).

The regional model was discretized in the areal dimensions using a variably spaced grid and cell sizes ranging from approximately $4,000 \times 5,000$ feet $\left(\mathrm{ft} ; 0.7 \mathrm{mi}^{2}\right)$ to $16,500 \times 16,500 \mathrm{ft}\left(9.8 \mathrm{mi}^{2}\right)$. At Barbour Pointe, the mesh resolution was $14,900 \times 16,100 \mathrm{ft}$, requiring refinement for the current model application. Each hydrogeologic unit was represented by one layer of grid cells in the vertical dimension.

Lateral boundaries for all layers of the regional model were designated as no-flow, with the exception of the southern and southwestern sides of layers 5, 6, and 7 (UFA, LFCU, and LFA, respectively), which were set as specified-head cells. Values assigned to specified-head cells were based on estimates of UFA head derived from the potentiometric-surface map for 1998 developed by Peck and others (1999).

The lowermost boundary of the regional model was designated as no-flow, corresponding to the lower confining unit of the Floridan aquifer system; the uppermost boundary was set as a head-dependent flow (or general-head) boundary representing the confined zone of the surficial aquifer system (fig. 1-2). The general-head boundary required a controlling specified-head and a conductance term to regulate groundwater flow between the top two layers of the model. The controlling head represented the water table in the onshore area and the freshwater equivalent of the saltwater head in the offshore area. In the onshore area, the conductance was set to limit the amount of recharge entering the system in any given grid cell for the 1980 and 2000 simulation periods to less-than-maximum recharge derived from base-flow estimates (Priest, 2004). The conductance established in the offshore area was set arbitrarily large, posing minimal resistance to flow in or out of the system, as little is known about hydraulic properties in this area.

Estimates of average annual pumpage were assigned in the regional model on the basis of county-aggregate and site-specific data. These data were used to develop pumpage distributions for the assumed steady-state conditions of 1980 and 2000 used for calibration. Pumpage was assigned to model layers 3 (Brunswick aquifer system), 5 (UFA), and 7 (LFA) on the basis of the open interval of wells. Pumping rates within a model cell were obtained by summing site-specific and nonsite-specific pumping rates corresponding to that model cell. Pumpage simulated by the model totaled 692 million gallons per day (Mgal/d) for 1980 and $798 \mathrm{Mgal} / \mathrm{d}$ for 2000 . Because pumpage during 2010 ( $799 \mathrm{Mgal} / \mathrm{d}$ ) was about the same as during 2000, the revised model used to evaluate groundwater flow near Barbour Pointe was within the same range of calibrated pumping conditions as the regional model. 


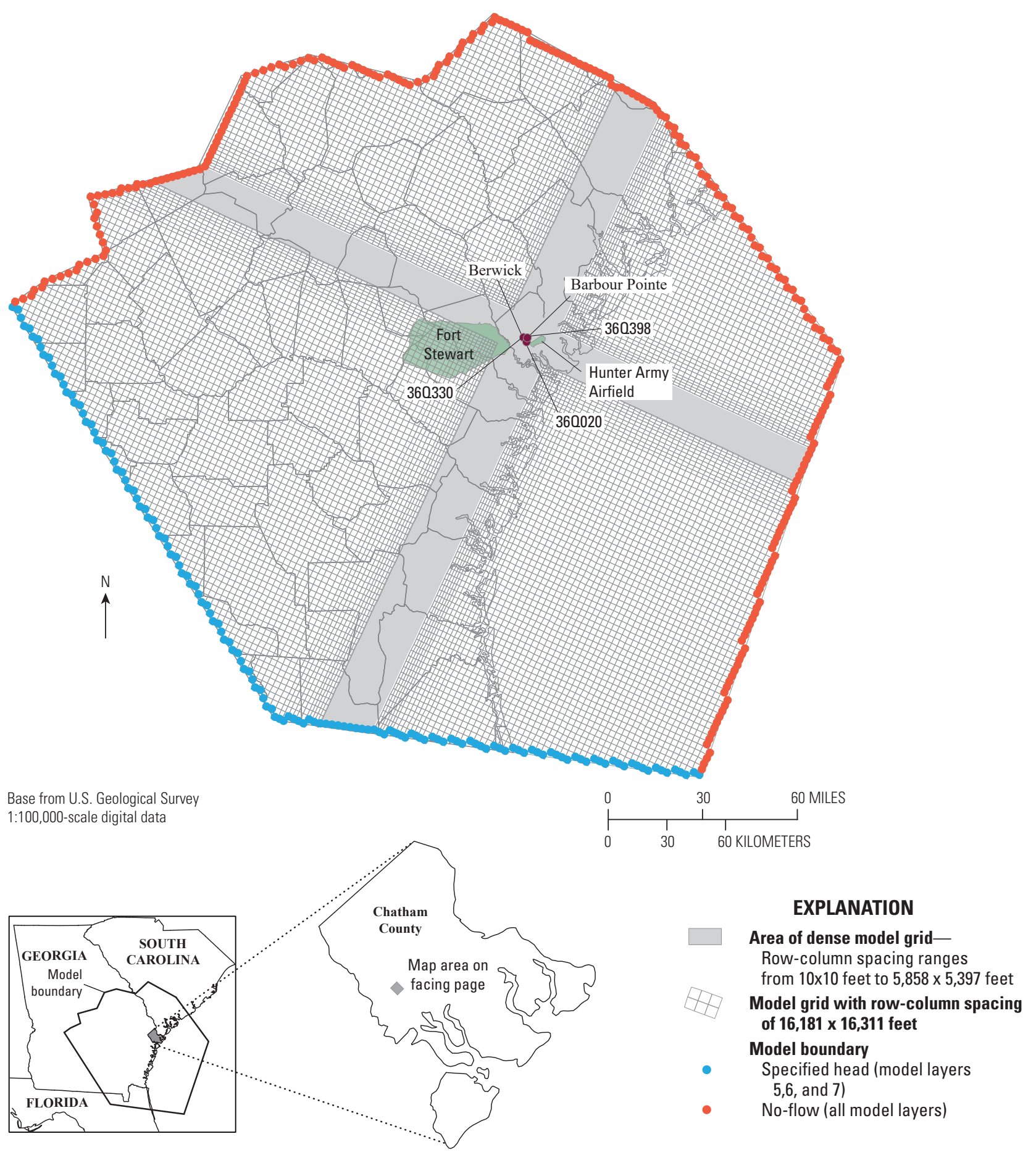

Figure 1-1A. Location of selected wells, regional groundwater model and boundary conditions, and revised model grid, city of Berwick, Fort Stewart, Barbour Pointe, Georgia, and vicinity. 


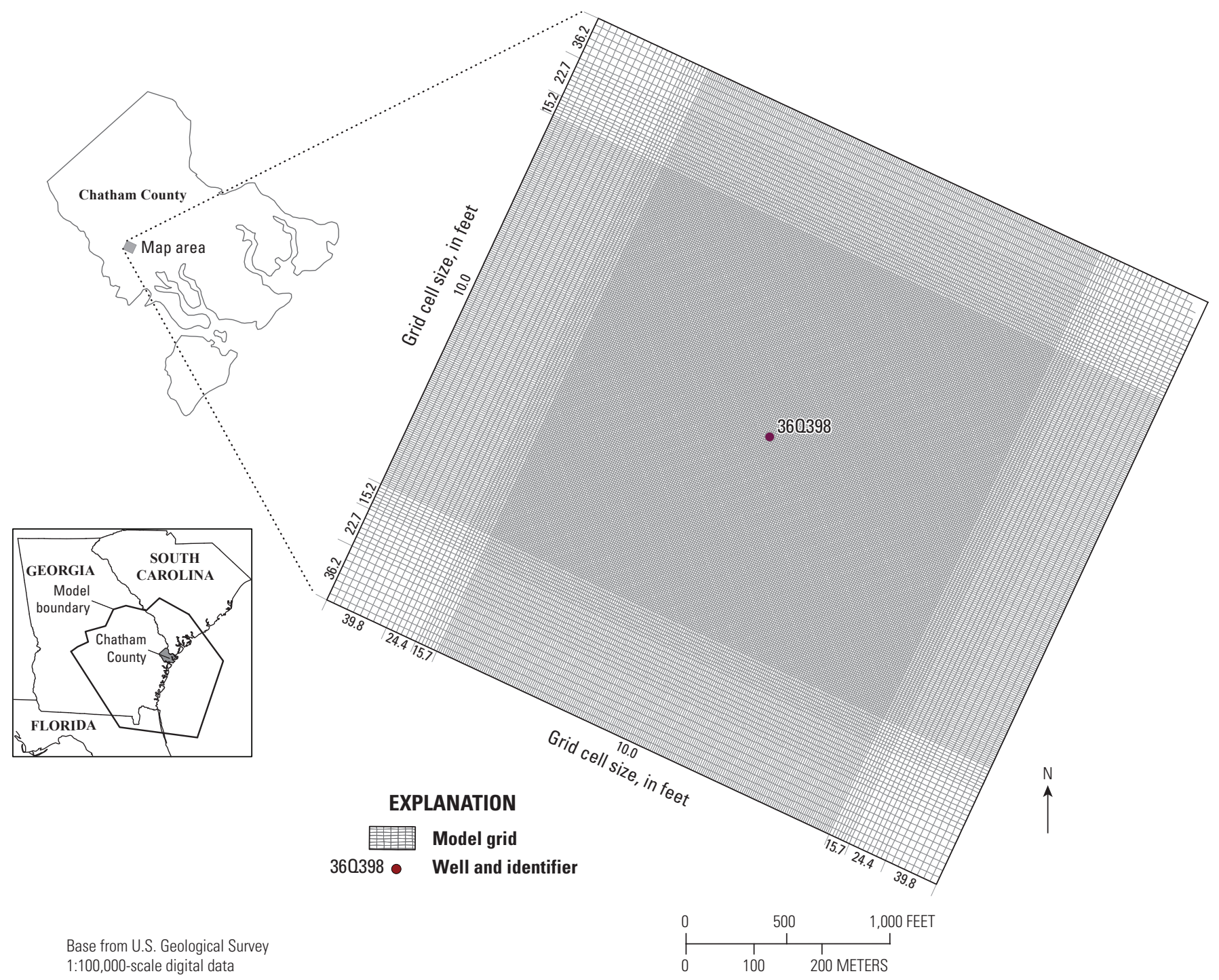

Figure 1-1B. Location of selected wells, regional groundwater model and boundary conditions, and revised model grid, city of Berwick, Fort Stewart, Barbour Pointe, Georgia, and vicinity. 


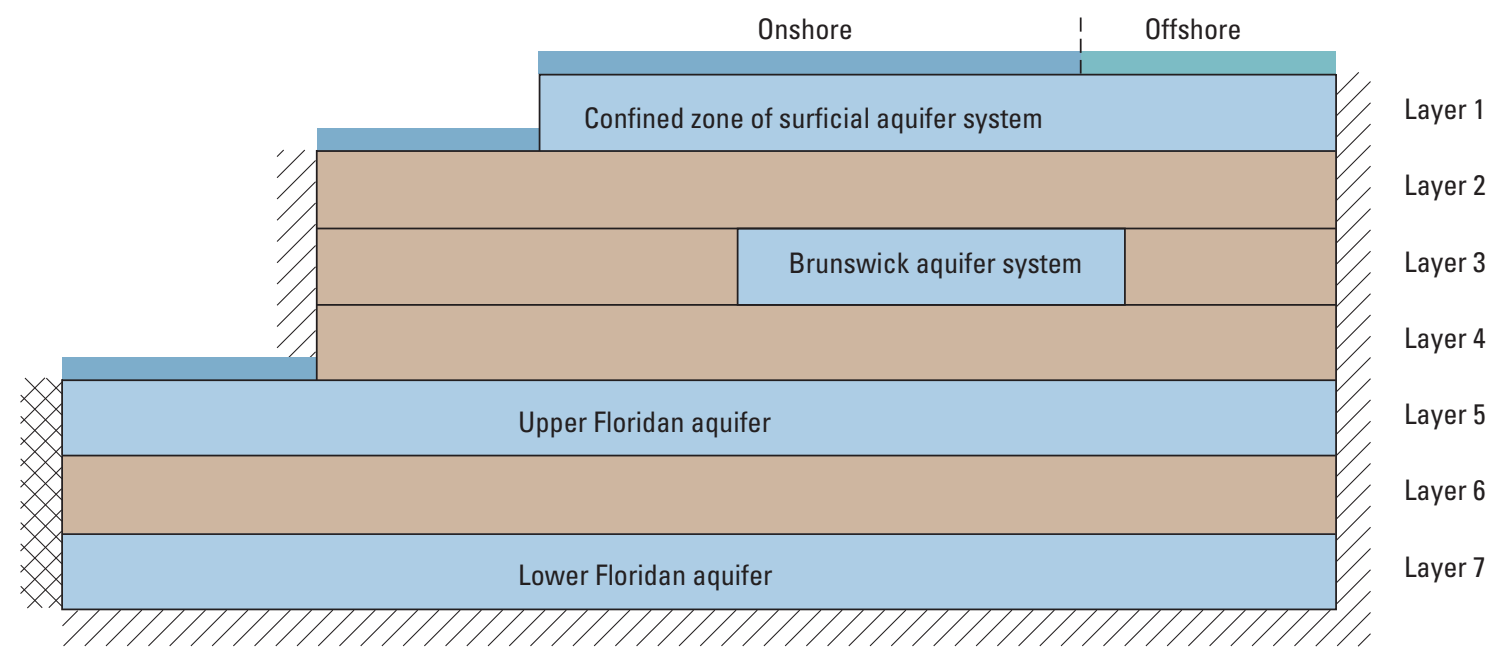

\section{EXPLANATION}

Aquifer

Semiconfining/confining unit

General head boundary - Represents water table or equivalent freshwater head that provides flow to underlying confined aquifers. Flow is restricted by a conductance term, which is equivalent to hydraulic conductivity

Onshore area-Water-table head

Offshore area-Equivalent freshwater head of overlying saltwater column

$1 / /$, No-flow boundary

XX No-flow or fixed-head boundary

Figure 1-2. Schematic diagram showing model layers and boundary conditions (from Payne and others, 2005). 


\section{Revisions to Regional Model}

The regional model of Payne and others (2005) was modified using hydrogeologic information obtained from field investigations at Barbour Pointe (Gonthier and Clarke, 2016), and from existing wells in the vicinity of Berwick Plantation near Berwick (Jordan, Jones, and Goulding, Inc., 2002), Pooler (Gonthier, 2012), Hunter Army Airfield (Williams, 2010), Rincon (Carter and Sloope, 2004), and Fort Stewart (Gonthier, 2011). These modifications involved addition of new hydraulic-property zones for vertical and horizontal hydraulic conductivity in the UFA and LFA and intervening semiconfining unit (LFCU). Modifications to the regional model that were made during previous investigations at Pooler (Cherry and Clarke, 2013) and Hunter Army Airfield in Chatham County (Clarke and others, 2010), Rincon in Effingham County (Cherry and Clarke, 2015), and Fort Stewart in Liberty County (Clarke and others, 2011) also were applied to the model developed for the current study. The revised model retained the original model layering and boundary conditions.

\section{Refinement of Grid Resolution}

Grid-cell dimensions were modified to variably spaced dimensions (fig. 1-1) that increase from the smallest cell size of 10×10 ft near well 36Q398 to a maximum size of about $16,181 \mathrm{ft}$ in the row direction and $16,311 \mathrm{ft}$ in the column direction. The orientation of the grid was rotated slightly in a clockwise manner to accommodate the finer mesh in the Barbour Pointe area. The revised model consists of 440 rows and 424 columns. The variably spaced grid used in the revised model contains aspect ratios between row and column dimensions as large as 1,013:1, which can lead to numerical errors (de Marsily, 1986, p. 351). Fortunately, these large aspect ratio grid cells are only in areas distant from Barbour Pointe and have little effect on simulation results in the area.

\section{Refinement of Hydraulic Conductivity Distribution}

Packer-slug tests and core analyses performed at Barbour Pointe during the course of this study and in previous studies at Hunter Army Airfield, Fort Stewart, and Pooler provided the basis for revising hydraulic-conductivity values assigned to these areas in the regional model (Payne and others, 2005). In the area outside of Barbour Pointe, values of vertical and horizontal hydraulic conductivity $\left(\mathrm{K}_{\mathrm{v}}\right.$ and $\mathrm{K}_{\mathrm{h}}$, respectively) correspond to values used (1) in the regional model (Payne and others, 2005); (2) in the area of Hunter Army Airfield, as simulated by Clarke and others (2010); (3) in the area of Fort Stewart, as simulated by Clarke and others (2011); and (4) in the area of Pooler, as simulated by Cherry and Clarke (2013) (fig. 1-3, table 1-1). Field testing at Barbour Pointe (Gonthier and Clarke, 2016) provided new information about the hydraulic properties of the UFA (layer 5) and LFA (layer 7) and enabled refinement of values that were used in the regional model. In addition, results of a 72-hour aquifer test conducted in the LFA provided information about drawdown in the LFA and in the overlying UFA, which guided revisions to $\mathrm{K}_{\mathrm{v}}$ and $\mathrm{K}_{\mathrm{h}}$ values from previous calibrated values near Barbour Pointe. Hydraulic conductivity of the LFCU was not measured at Barbour Pointe, so results from core analysis and packer-slug tests at Hunter Army Airfield and Pooler were applied to the model (Williams, 2010; Gonthier, 2012).

New hydraulic-property zones were developed for this study on the basis of field data collected at Berwick Plantation near Berwick (Faye and Gill, 2005), Barbour Pointe (Gonthier and Clarke, 2016), Hunter Army Airfield (Williams, 2010), Fort Stewart (Gonthier, 2011), and Pooler (Gonthier, 2012). Hydraulic-property zones were added as follows (fig. 1-3, table 1-1):

- UFA (layer 5): Zone F13 added at Hunter Army Airfield and expanded northwestward to include Pooler and Barbour Pointe; zone F14 added at Fort Stewart.

- LFCU (layer 6): Zone LFC2 added at Hunter Army Airfield and expanded northwestward to include Pooler and Barbour Pointe; zone LFC3 added at Fort Stewart.

- LFA (layer 7): Zone LF2 added at Hunter Army Airfield and expanded northwestward to include Pooler and Barbour Pointe; zone LF3 added at Fort Stewart.

Each hydraulic-property zone was initially assigned a $\mathrm{K}_{\mathrm{h}}$ and $\mathrm{K}_{\mathrm{y}}$ value on the basis of results of field testing at each site. With the exception of $\mathrm{K}_{\mathrm{v}}$ for the LFCU, values were adjusted slightly to calibrate water-level changes in the UFA and LFA observed during 72-hour aquifer tests at the two sites. Values for $\mathrm{K}_{\mathrm{v}}$ of the LFCU were assigned the median value measured during previous studies, 0.2 foot per day ( $\mathrm{ft} / \mathrm{d})$, measured at Hunter Army Airfield (Williams, 2010). This value was held constant to ensure computed leakage simulations were conservative, that is, similar to Hunter Army Airfield and Pooler, because $\mathrm{K}_{\mathrm{v}}$ was not measured at the Barbour Pointe site.

For the UFA (layer 5), zone F13 for the Hunter Army Airfield study (Clarke and others, 2010) was expanded from a 114- $\mathrm{mi}^{2}$ area in the Hunter Army Airfield model, to $221 \mathrm{mi}^{2}$ in the Pooler and Barbour Pointe models. Here, the UFA was assigned $\mathrm{K}_{\mathrm{h}}$ and $\mathrm{K}_{\mathrm{y}}$ values of $90 \mathrm{ft} / \mathrm{d}$ each (table 1-1), which is slightly higher than the $70-\mathrm{ft} / \mathrm{d}$ value assigned in the original regional model. Multiplying $90 \mathrm{ft} / \mathrm{d}$ by the thickness of the aquifer gives an estimated transmissivity of 50,755 feet squared per day $\left(\mathrm{ft}^{2} / \mathrm{d}\right)$ at Barbour Pointe, which is about 85 percent of the $60,000-\mathrm{ft}^{2} / \mathrm{d}$ value reported by aquifer testing (Gonthier and Clarke, 2016). 

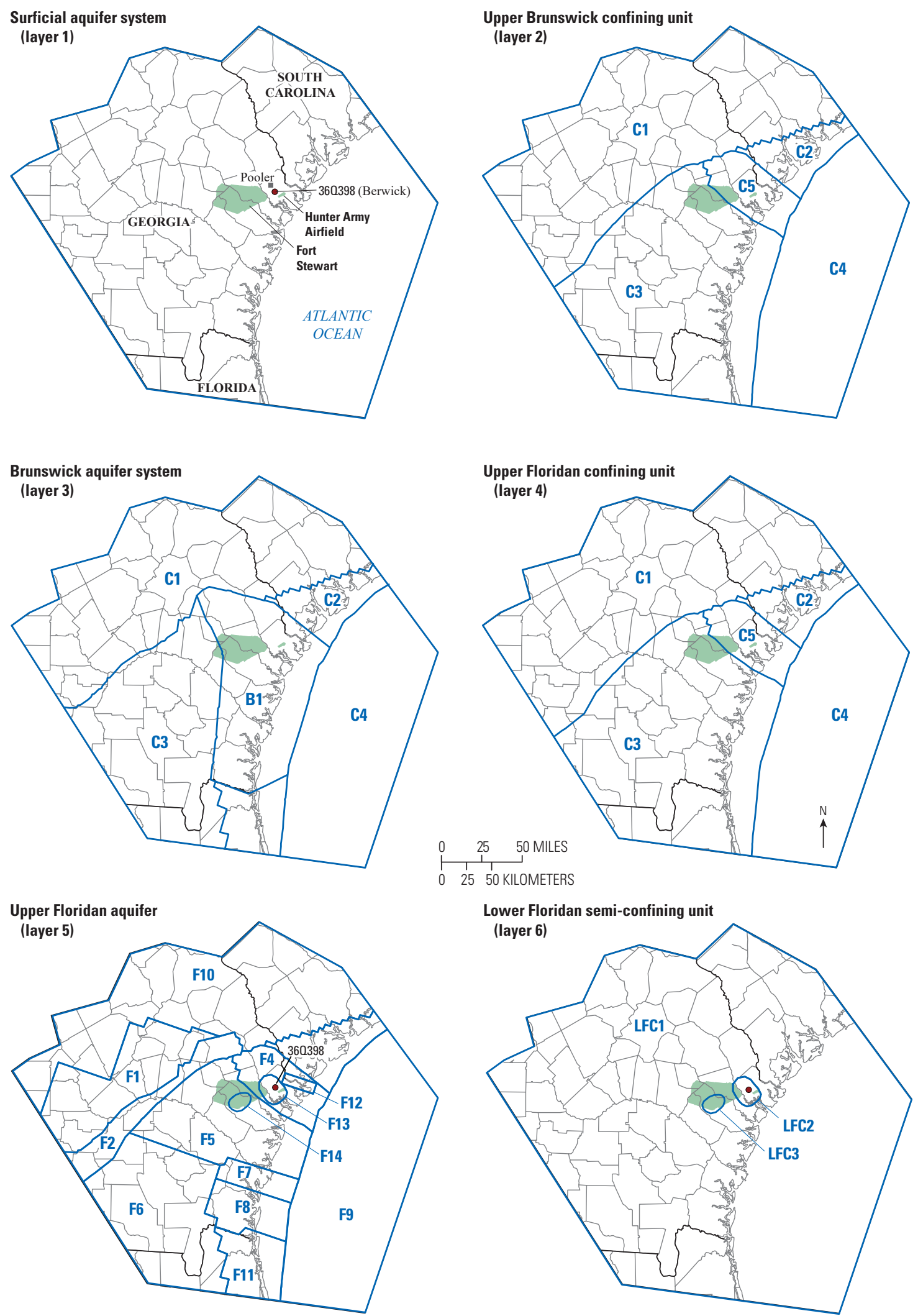

Base from U.S. Geological Survey 1:100,000-scale digital data

Figure 1-3 (pages 28 and 29). Simulated hydraulic-property zones by model layer. Table 1-1 lists hydraulic conductivity values assigned to zones. 
Table 1-1. Horizontal and vertical hydraulic conductivity values assigned to hydraulic-property zones for the original (Payne and others, 2005) and revised groundwater-flow models.

[-, not applicable]

\begin{tabular}{|c|c|c|c|c|c|c|c|}
\hline \multirow{3}{*}{ Unit } & \multirow{3}{*}{ Layer } & \multicolumn{3}{|c|}{ Payne and others (2005) } & \multicolumn{3}{|c|}{ Revised model } \\
\hline & & \multirow{2}{*}{$\begin{array}{c}\text { Hydraulic } \\
\text { property zone }\end{array}$} & \multicolumn{2}{|c|}{$\begin{array}{l}\text { Hydraulic conductivity, in } \\
\text { feet per day }\end{array}$} & \multirow{2}{*}{$\begin{array}{c}\text { Hydraulic } \\
\text { property zone }\end{array}$} & \multicolumn{2}{|c|}{$\begin{array}{l}\text { Hydraulic conductivity, in } \\
\text { feet per day }\end{array}$} \\
\hline & & & Horizontal & Vertical & & Horizontal & Vertical \\
\hline Surficial aquifer & 1 & - & 70 & 70 & 1 & 70 & 70 \\
\hline Confining unitr & 2 & $\begin{array}{l}\mathrm{C} 1 \\
\mathrm{C} 2 \\
\mathrm{C} 3 \\
\mathrm{C} 4 \\
\mathrm{C} 5\end{array}$ & $\begin{array}{l}0.00002 \\
0.20000 \\
0.00001 \\
0.00010 \\
0.00010\end{array}$ & $\begin{array}{l}0.00002 \\
0.20000 \\
0.00001 \\
0.00010 \\
0.00010\end{array}$ & $\begin{array}{l}\mathrm{C} 1 \\
\mathrm{C} 2 \\
\mathrm{C} 3 \\
\mathrm{C} 4 \\
\mathrm{C} 5\end{array}$ & $\begin{array}{l}0.00002 \\
0.20000 \\
0.00001 \\
0.00010 \\
0.00010\end{array}$ & $\begin{array}{l}0.00002 \\
0.20000 \\
0.00001 \\
0.00010 \\
0.00010\end{array}$ \\
\hline Brunswick aquifer system & 3 & $\begin{array}{l}\mathrm{B} 1 \\
\mathrm{C} 1 \\
\mathrm{C} 2 \\
\mathrm{C} 3 \\
\mathrm{C} 4\end{array}$ & $\begin{array}{l}50 \\
0.00002 \\
0.20000 \\
0.00001 \\
0.00010\end{array}$ & $\begin{array}{l}50 \\
0.00002 \\
0.20000 \\
0.00001 \\
0.00010\end{array}$ & $\begin{array}{l}\mathrm{B} 1 \\
\mathrm{C} 1 \\
\mathrm{C} 2 \\
\mathrm{C} 3 \\
\mathrm{C} 4\end{array}$ & $\begin{array}{l}50 \\
0.00002 \\
0.20000 \\
0.00001 \\
0.00010\end{array}$ & $\begin{array}{l}50 \\
0.00002 \\
0.20000 \\
0.00001 \\
0.00010\end{array}$ \\
\hline Confining unit & 4 & $\begin{array}{l}\mathrm{C} 1 \\
\mathrm{C} 2 \\
\mathrm{C} 3 \\
\mathrm{C} 4 \\
\mathrm{C} 5\end{array}$ & $\begin{array}{l}0.00002 \\
0.20000 \\
0.00001 \\
0.00010 \\
0.00010\end{array}$ & $\begin{array}{l}0.00002 \\
0.20000 \\
0.00001 \\
0.00010 \\
0.00010\end{array}$ & $\begin{array}{l}\mathrm{C} 1 \\
\mathrm{C} 2 \\
\mathrm{C} 3 \\
\mathrm{C} 4 \\
\mathrm{C} 5\end{array}$ & $\begin{array}{l}0.00002 \\
0.20000 \\
0.00001 \\
0.00010 \\
0.00010\end{array}$ & $\begin{array}{l}0.00002 \\
0.20000 \\
0.00001 \\
0.00010 \\
0.00010\end{array}$ \\
\hline Upper Floridan aquifer & 5 & $\begin{array}{l}\text { F1 } \\
\text { F2 } \\
\text { F3 } \\
\text { F4 } \\
\text { F5 } \\
\text { F6 } \\
\text { F7 } \\
\text { F8 } \\
\text { F9 } \\
\text { F10 } \\
\text { F11 } \\
\text { F12 } \\
- \\
-\end{array}$ & $\begin{array}{r}34 \\
2 \\
100 \\
70 \\
394 \\
2,819 \\
150 \\
2,727 \\
100 \\
56 \\
94 \\
25 \\
- \\
-\end{array}$ & $\begin{array}{r}34 \\
2 \\
100 \\
70 \\
394 \\
819 \\
150 \\
727 \\
100 \\
56 \\
94 \\
25 \\
- \\
-\end{array}$ & $\begin{array}{l}\text { F1 } \\
\text { F2 } \\
\text { F3 } \\
\text { F4 } \\
\text { F5 } \\
\text { F6 } \\
\text { F7 } \\
\text { F8 } \\
\text { F9 } \\
\text { F10 } \\
\text { F11 } \\
\text { F12 } \\
\text { F13 } \\
\text { F14 }\end{array}$ & $\begin{array}{r}34 \\
2 \\
100 \\
70 \\
394 \\
2,819 \\
150 \\
2,727 \\
100 \\
56 \\
94 \\
25 \\
90 \\
398\end{array}$ & $\begin{array}{r}34 \\
2 \\
100 \\
70 \\
394 \\
2,819 \\
150 \\
2,727 \\
100 \\
56 \\
94 \\
25 \\
90 \\
398\end{array}$ \\
\hline Semiconfining unit & 6 & - & $\begin{array}{l}0.020000 \\
- \\
-\end{array}$ & $\begin{array}{l}0.020000 \\
- \\
-\end{array}$ & $\begin{array}{l}\text { LFC1 } \\
\text { LFC2 } \\
\text { LFC3 }\end{array}$ & $\begin{array}{l}0.02000 \\
2.0 \\
10.00000\end{array}$ & $\begin{array}{l}0.02000 \\
0.2 \\
0.2\end{array}$ \\
\hline Lower Floridan aquifer & 7 & - & $\begin{array}{c}10.00000 \\
- \\
-\end{array}$ & ${ }^{1}-$ & $\begin{array}{l}\text { LF1 } \\
\text { LF2 } \\
\text { LF3 }\end{array}$ & $\begin{array}{l}10 \\
114 \\
15.80000\end{array}$ & $\begin{array}{r}10 \\
13.4 \\
1.6\end{array}$ \\
\hline
\end{tabular}
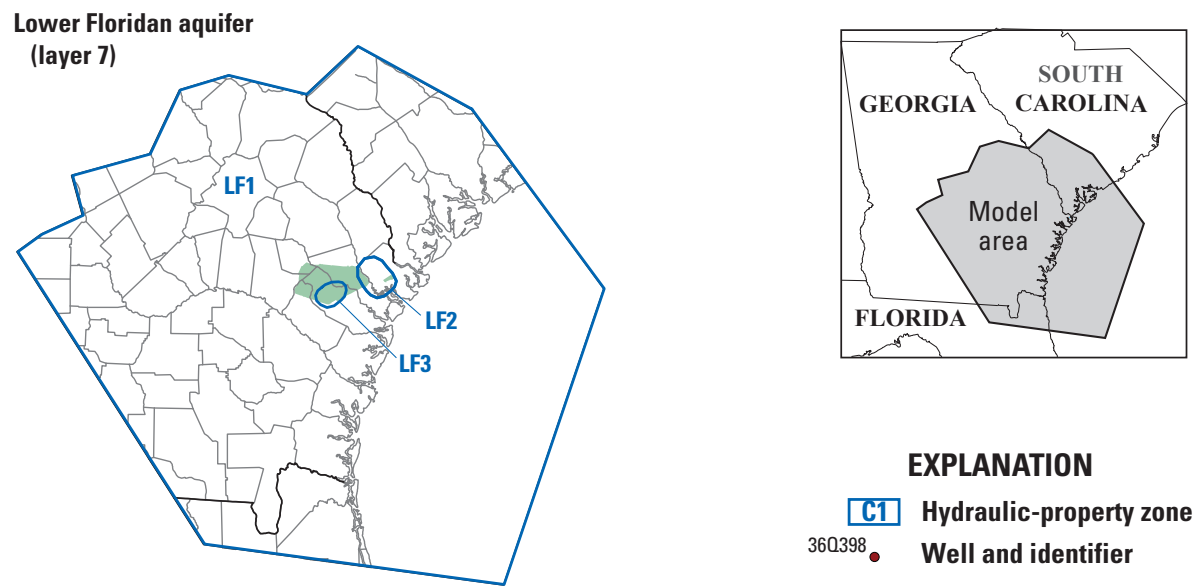

\section{EXPLANATION}


For the revised model in the Fort Stewart area, zone F14 was subdivided from regional model zone F5 and assigned slightly higher $\mathrm{K}_{\mathrm{h}}$ and $\mathrm{K}_{\mathrm{v}}$ values of $398 \mathrm{ft} / \mathrm{d}$ each, which is based on results of aquifer testing (table 1-1). The new zone value of $398 \mathrm{ft} / \mathrm{d}$ represents a 1-percent increase from the 394-ft/d value assigned to zone F5 in the regional model (Payne and others, 2005). Multiplying $398 \mathrm{ft} / \mathrm{d}$ by the thickness of the aquifer gives an estimated transmissivity of $100,000 \mathrm{ft}^{2} / \mathrm{d}$, which matches the results of field testing (Gonthier, 2011).

In the regional model (Payne and others, 2005), the Lower Floridan semiconfining unit (LFCU; layer 6) was assigned a single $K_{h}$ and $K_{v}$ value of $0.02 \mathrm{ft} / \mathrm{d}$ (table 1-1). Field data were used as a basis to delineate one additional zone in the vicinity of Hunter Army Airfield (LFC2) and one additional zone at Fort Stewart (LFC3). At Fort Stewart, zone LFC3 in layer 6 covers an area identical to that of zone F14 in layer 5, with a calibrated $\mathrm{K}_{\mathrm{h}}$ value of 10 and a $\mathrm{K}_{\mathrm{v}}$ value of 0.2 ; these values are within the range of field testing (Gonthier, 2011). Zone LFC2 was expanded northwestward from an area of $114 \mathrm{mi}^{2}$ in the Hunter Army Airfield model, to $221 \mathrm{mi}^{2}$ in the Pooler and Barbour Pointe models. Within zone LFC2 in the revised model, the LFCU was assigned a $\mathrm{K}_{\mathrm{v}}$ value of $0.2 \mathrm{ft} / \mathrm{d}$, which approximates the median reported value of previous investigations completed in the area, based on results at Hunter Army Airfield (Clarke and others, 2010). A K $\mathrm{h}_{\mathrm{h}}$ value of $2 \mathrm{ft} / \mathrm{d}$ was assigned to the LFCU in zone LFC2 based on a reported $\mathrm{K}_{\mathrm{h}} / \mathrm{K}_{\mathrm{v}}$ ratio of 8.5:1 at the Hunter Army Airfield site.

Hydraulic properties for model layer 7, which represents the LFA, were designated as a single zone in the regional model of Payne and others (2005), having uniform $K_{h}$ and $K_{v}$ values of $10 \mathrm{ft} / \mathrm{d}$ each (table 1-1). Additional zones for the LFA were designated on the basis of field studies at Pooler, Hunter Army Airfield, Fort Stewart, and Barbour Pointe. At Fort Stewart, zone LF3 covers an area identical to zones F14 and LFC3, containing a calibrated $\mathrm{K}_{\mathrm{h}}$ value of $15.8 \mathrm{ft} / \mathrm{d}$ and a $\mathrm{K}_{\mathrm{v}}$ value of $1.6 \mathrm{ft} / \mathrm{d}$. Multiplying the $\mathrm{K}_{\mathrm{h}}$ value by the simulated thickness of the aquifer gives an estimated transmissivity of $5,200 \mathrm{ft}^{2} / \mathrm{d}$ at Fort Stewart, which is similar to results of field testing (Gonthier, 2011).

Zone LF2 in layer 7 was expanded northwestward from an area of $114 \mathrm{mi}^{2}$ in the Hunter Army Airfield model, to $221 \mathrm{mi}^{2}$ in the Pooler and Barbour Pointe models. Zone LF2 in layer 7 covers an area identical to zones F13 in layer 5 and LFC2 in layer 6 with a calibrated $\mathrm{K}_{\mathrm{h}}$ value of $114 \mathrm{ft} / \mathrm{d}$, compared to $88 \mathrm{ft} / \mathrm{d}$ in the calibrated Pooler model (Cherry and Clarke, 2013). Multiplying the $\mathrm{K}_{\mathrm{h}}$ value by the simulated thickness of the aquifer gives an estimated transmissivity of $5,647 \mathrm{ft}^{2} / \mathrm{d}$, which is slightly greater than the $5,100-\mathrm{ft}^{2} / \mathrm{d}$ value derived from field testing at Barbour Pointe ( Gonthier and Clarke, 2016). A K $\mathrm{h}_{\mathrm{h}}$ value of $13.4 \mathrm{ft} / \mathrm{d}$ was assigned to the LFA in zone LF2 based on a reported $\mathrm{K}_{\mathrm{h}} / \mathrm{K}_{\mathrm{v}}$ ratio of 8.5:1 at the Hunter Army Airfield site (table 1-1).

\section{Simulation of Observed Drawdown in Pumped Well}

Drawdown calculated by the revised model represents the average drawdown for a node located at the areal center of the grid cell containing the pumped well. This average drawdown under-represents the observed drawdown in the actual pumped well 36Q398. Because the area of the grid cell containing the pumped well (10 square feet $\left[\mathrm{ft}^{2}\right]$ ) is much larger than the area defined by the 8 -inch (in.) well diameter $\left(0.35 \mathrm{ft}^{2}\right)$, drawdown at the pumped well can be adjusted on the basis of the proportional increase in area attributed to the grid cell in comparison with the area of the pumped well using the following equation (Peaceman, 1983):

$$
S_{p}=S_{b}+\left[Q * \ln \left(r_{e} / r_{w}\right) / 2 \pi\left(T_{x x} T_{y y}\right)^{0.5}\right],
$$

where

$S_{p} \quad$ is adjusted drawdown in the pumped well, in feet;

$S_{b} \quad$ is simulated drawdown in the pumped well, in feet;

$Q \quad$ is pump discharge, in cubic feet per day $(144,375)$;

$r_{e} \quad$ is equivalent well block radius, in feet (5);

$r_{w} \quad$ is well radius, in feet (0.5);

$T_{x x} \quad$ is transmissivity in the $\mathrm{x}$ direction, in feet squared per day $(5,647)$; and

$T_{y y} \quad$ is transmissivity in the y direction, in feet squared per day $(5,647)$.

Results of this equation indicated that simulated values of drawdown at the center of the grid cell containing pumped well 36Q398 would under-represent the observed drawdown by $9.37 \mathrm{ft}$ for a pumping rate of 750 gallons per minute (gal/min). A similar analysis of an UFA well pumped at a rate of $240 \mathrm{gal} / \mathrm{min}$, having a well radius of $3 \mathrm{in}$. and a value of $50,755 \mathrm{ft}^{2} / \mathrm{d}$ for transmissivity indicates that the simulated drawdown in the grid cell containing the pumped well underrepresents the observed drawdown at the pumped well by about $0.33 \mathrm{ft}$. Simulated drawdown for the UFA and LFA were adjusted using these correction factors and compared with field observations for model calibration.

\section{Comparison of Revised to Original Regional Model}

Because the regional model of Payne and others (2005) was modified by changing grid cell sizes and assigning different hydraulic properties in and near Barbour Pointe, a comparison of results from the two models ensures that the revised model is an accurate representation of groundwater flow. Simulation results indicate that water-level residuals and the water budget for the revised regional model are similar to the original model of Payne and others (2005), and thus, both 
models provide similar simulation of the hydrologic system (tables 1-2, 1-3). These results were expected because model revisions were limited to $114-$ and $221-\mathrm{mi}^{2}$ areas representing less than 1 percent of the model area.

Mean water-level residual for layer 3 (Brunswick aquifer system) shifted from a positive bias in the original model $(1.79 \mathrm{ft})$ to a negative bias in the revised model $(-2.97 \mathrm{ft})$, as shown on the residuals map and graphs (table 1-2, figs. 1-4, $1-5)$. For layer 5 (UFA), the mean residual remained negative in the revised model, changing from -0.84 to $-3.59 \mathrm{ft}$. The mean residual for layer 7 (LFA) remained positive in the revised model but was closer to zero than the value from the original model, changing from 5.2 to $2.35 \mathrm{ft}$.

The root-mean-square error (RMSE) of water-level residuals for layer $3(11.2 \mathrm{ft})$ in the revised model is nearly double that of the original regional model $(5.91 \mathrm{ft})$ but is considered acceptable for the purpose of the modified model, which is to simulate flow in the UFA and LFA. Most of the increase in the RMSE for layer 3 can be attributed to two wells in the Brunswick aquifer system that had water-level residuals of about $-19 \mathrm{ft}$ each (figs. 1-4, 1-5). These wells are adjacent to one another in the same model cell, in an area where the grid size of the revised model is more than four times larger than in the original regional model. This larger grid size reduced the capability of the model to simulate steep gradients in the vicinity of the Savannah-area cone of depression and resulted in a large residual. Because the relatively large grid size and related increase in RMSE for layer 3 occurred away from the area of high grid resolution in the vicinity of Barbour Pointe, simulated heads in the Barbour Pointe area were only slightly affected.

The RMSE of residuals for layer 5 was similar for the original $(9.94 \mathrm{ft})$ and revised $(9.90 \mathrm{ft})$ models. For layer 7 , the RMSE of residuals decreased from $9.15 \mathrm{ft}$ in the regional model to $8.75 \mathrm{ft}$ in the revised model.

Simulated water budgets for the regional and revised models were similar, with most variation occurring in layers 1 and 5 (table 1-3). The revised model showed

- decreased recharge from the general-head boundary in layers 1 and 2;

- decreased discharge to the general-head boundary in layers 1,2 , and 5; and

- increased inflow and outflow along lateral specifiedhead boundaries in layer 5 .

Table 1-2. Water-level calibration statistics for the original (Payne and others, 2005) and revised regional models, base case (year 2000) simulation.

[Residual equals simulated minus observed head]

\begin{tabular}{|c|c|c|c|c|c|c|c|c|c|c|}
\hline \multirow{2}{*}{$\begin{array}{l}\text { Hydro- } \\
\text { geologic } \\
\text { unit }\end{array}$} & \multirow{2}{*}{$\begin{array}{l}\text { Model } \\
\text { layer }\end{array}$} & \multirow{2}{*}{$\begin{array}{c}\text { Number of } \\
\text { observations }\end{array}$} & \multicolumn{2}{|c|}{$\begin{array}{c}\text { Minimum residual, } \\
\text { in feet }\end{array}$} & \multicolumn{2}{|c|}{$\begin{array}{c}\text { Maximum residual, } \\
\text { in feet }\end{array}$} & \multicolumn{2}{|c|}{$\begin{array}{c}\text { Mean of residuals, } \\
\text { in feet }\end{array}$} & \multicolumn{2}{|c|}{$\begin{array}{l}\text { Root mean square of } \\
\text { residuals, in feet }\end{array}$} \\
\hline & & & $\begin{array}{c}\text { Original } \\
\text { model }\end{array}$ & $\begin{array}{c}\text { Revised } \\
\text { model }\end{array}$ & $\begin{array}{c}\text { Original } \\
\text { model }\end{array}$ & $\begin{array}{l}\text { Revised } \\
\text { model }\end{array}$ & $\begin{array}{c}\text { Original } \\
\text { model }\end{array}$ & $\begin{array}{c}\text { Revised } \\
\text { model }\end{array}$ & $\begin{array}{c}\text { Original } \\
\text { model }\end{array}$ & $\begin{array}{l}\text { Revised } \\
\text { model }\end{array}$ \\
\hline $\begin{array}{c}\text { Brunswick } \\
\text { aquifer } \\
\text { system }\end{array}$ & 3 & 10 & -7.67 & -19.0 & 13.3 & 14.3 & 1.79 & -2.97 & 5.91 & 11.2 \\
\hline $\begin{array}{l}\text { Lower } \\
\text { Floridan } \\
\text { aquifer }\end{array}$ & 7 & 11 & -3.62 & -5.10 & 21.5 & 25.0 & 5.20 & 2.35 & 9.15 & 8.75 \\
\hline
\end{tabular}


Table 1-3. Comparison of simulated water budget by model layer between the original (Payne and others, 2005) and revised regional models, base case (year 2000) simulation.

[Values may not sum to totals because of independent rounding. $<$, less than]

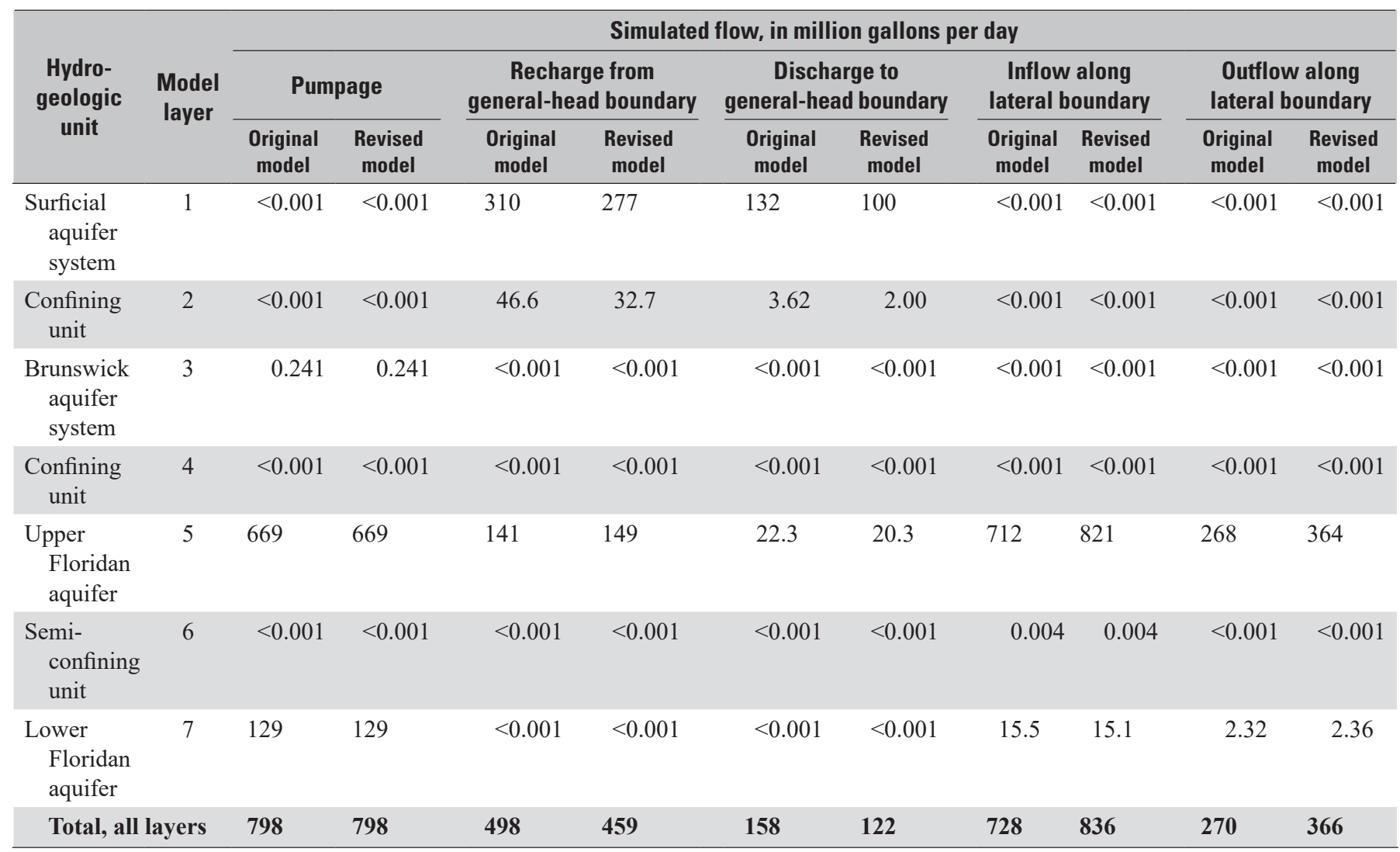



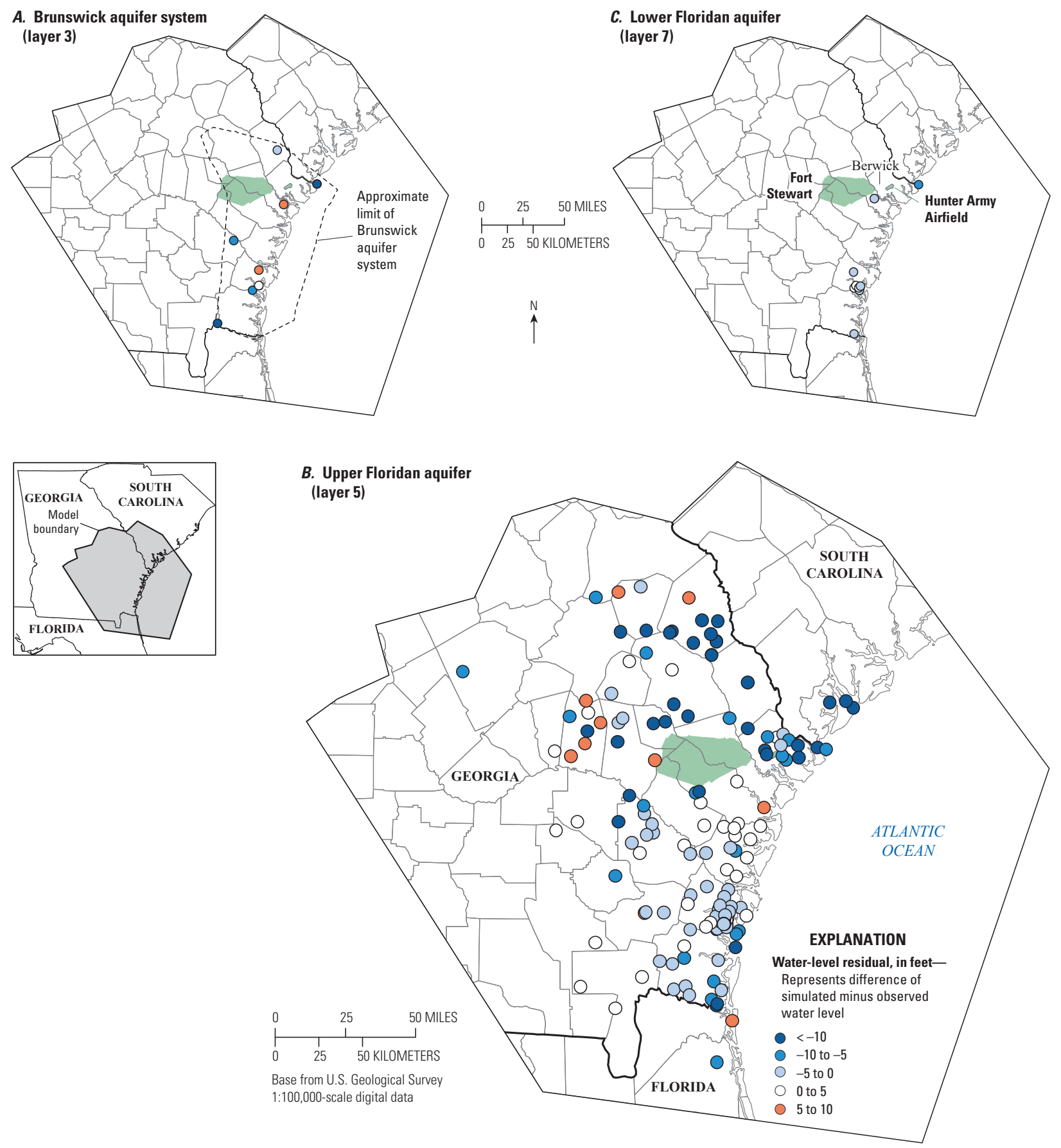

Figure 1-4. Difference between simulated and observed water levels (residuals) by model layer for 2000, revised regional flow model. $A$, Brunswick aquifer system (layer 3), $B$, Upper Floridan aquifer (layer 5), and $C$, Lower Floridan aquifer (layer 7). Residuals by model layer for 2000. 

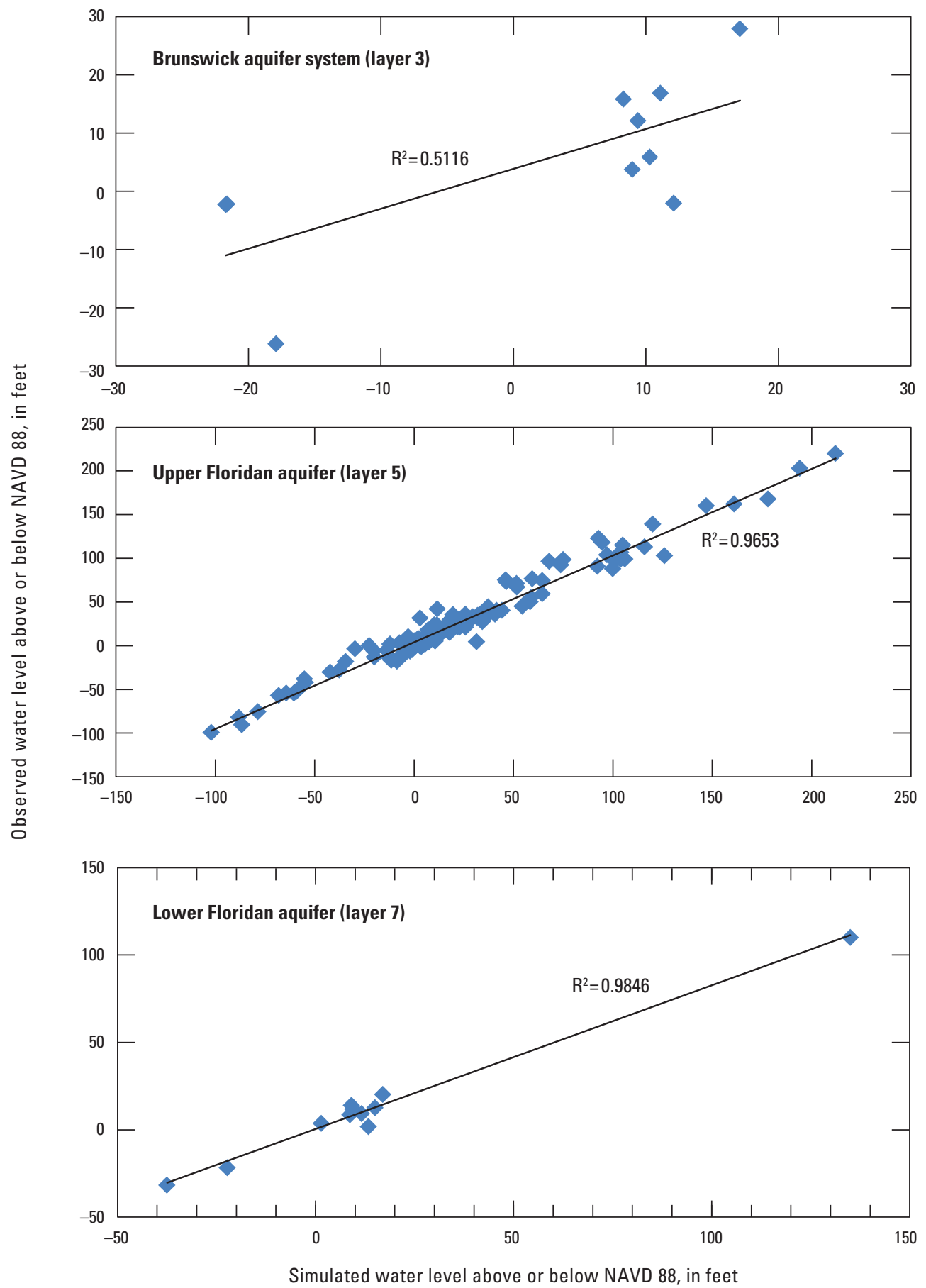

Figure 1-5. Observed and simulated water levels in model layers 3, 5, and 7, revised groundwater model. 
Manuscript approved August 1, 2017

For additional information regarding this publication, please contact:

South Atlantic Water Science Center

U.S. Geological Survey

720 Gracern Road

Stephenson Center, Suite 129

Columbia, SC 29210

Or visit the South Atlantic Water Science Center website at https://sc.water.usgs.gov/

Prepared by the USGS Science Publishing Network Lafayette and Reston Publishing Service Centers

Edited by Mike Deacon

Illustrations and layout by Jeffrey L. Corbett 
은

है

을.

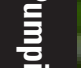

흘.

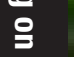

宗
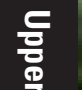

끈

을.

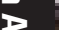

믈

害

$\cong$

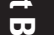

흠

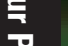

을

응.

I

क्ञ

․․ㄹ.

言

三

(1)

용.

. 